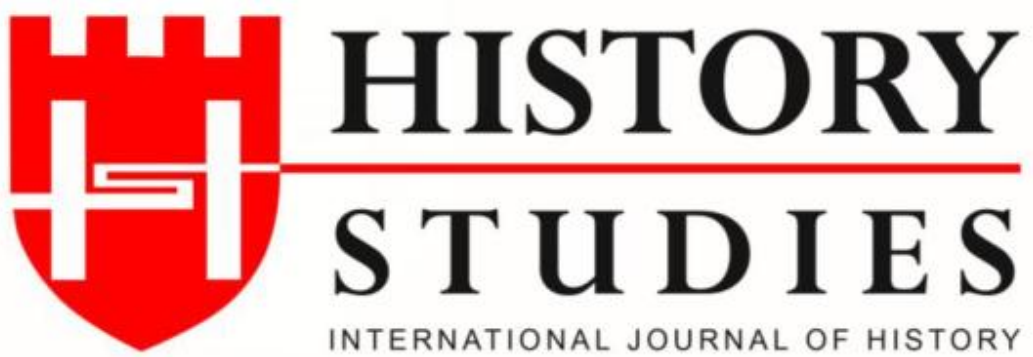

ISSN: 13094173 (Online) 1309 - 4688 (Print)

Volume 10 Issue 10, A Tribute to Prof. Dr. Yilmaz KURT, p. 207-232, December 2018

DOI Number: 10.9737/hist.2018.699

\title{
Bir Jön Türk ve Arnavut Milliyetçisi: Derviş Hima (1872-1928)
} A Young Turk and Albanian Nationalist: Dervish Hima (1872-1928)

\author{
Dr. Said OLGUN \\ (ORCID: 0000-0002-9171-2788) \\ Siirt Üniversitesi - Siirt
}

Öz: 1877-1878 Osmanlı-Rus Harbi, Osmanlı Devleti ve devlet içerisinde yaşayan etnik unsurlar için tam bir dönüm noktası olmuştur. II. Abdülhamid'in savaşı bahane ederek Meclis-i Mebusanı süresiz olarak tatil etmesi, Kanun-i Esasiyi rafa kaldırması ve ilerleyen yıllardaki uygulamaları, Jön Türk hareketi etrafinda örgütlenen bir muhalefetin oluşmasına sebep olmuştur. Öte yandan savaş esnasında Osmanlı Devleti'nin içine düşı̈̈̆̈ü müş̧kül durum ve savaş sonunda imzalanan Ayastefanos Antlaşması, Arnavutları, Osmanlı Devletinin kendilerini koruyamayacağ düşüncesine sevk etmiştir. Buna bağlı olarak da çevrelerini kuşatan Sırbistan, Karadağ ve Yunanistan'a karşı hem yaşadıkları toprakları hem de milli varlıklarını muhafaza etmek için millî bir bilincin oluşmasına yönelik çalı̧̧malar yapmaya başlamışlardır. Buna bağlı olarak son dönem Osmanlı aydınlarının birçoğunda olduğu gibi Arnavut aydınlar da Osmanlı kimliğine sıkı slkıya bağlllıkla birlikte etnik kökenlerini ve kimliklerini de ön plana çıkarmaya başlamışlardır.

Bu çalışmada hem Jön Türk hareketinin hem de Arnavut milliyetçiliğinin önde gelen isimlerinden biri olan Derviş Hima'nın hayatı, siyasî faaliyetleri ve eserleri hakkında bilgi verilmiştir. Çalışmanın odak noktasını 1897-1912 yılları arasındaki faaliyetleri, Jön Türk ve Arnavut milliyetçisi ağlarla kurduğu ilişkiler ile II. Abdülhamid'e karşı yürüttü̈̆̈̈ muhalefet ve Arnavut millî kimliğinin inşası sürecinde yayımladı̆̆ eserler oluşturmaktadır.

Anahtar Kelimeler: Derviş Hima, Jön Türk, Arnavut Milliyetçiliği, Arnavutluk, Arnavut Gazetesi

Abstract: The 1877-1878 Russo-Turkish war was precisely a turning point for the Ottoman Empire and the ethnic groups living in that state. Abdulhamid II's indefinitely dismissing of the First Turkish Parliament using the war as an excuse, putting aside the Ottoman basic law, and his other applications throughout the following years, led to the formation of an opposition organized around the Young Turks movement. On the other hand, the ordeal that the Ottoman Empire went through during the war and the treaty of San Stefano signed after the war drove Albanians to the concerns that the Ottoman Empire would fail to protect them. Thus, they started to take action towards constructing a national consciousness in order to both protect their lands and national identities against Serbia, Montenegro and Greece that circumvent them. Accordingly, as with many of the late period Ottoman intellectuals, Albanian intellectuals also began to bring forward their ethnic roots and identities, despite their rigorous devotion to the Ottoman identity.

In this study, the life, political activities and works of Dervish Hima who is one of the leading figures of both the Young Turks movement and Albanian nationalism, is explained. His activities between 1897 and 1912, his relations with the Young Turks and Albanian nationalist networks, the opposition he pursued against Abdulhamid II and his works published in the construction process of Albanian identity constitute the focal point of this study.

Keywords: Dervish Hima, Young Turk, Albanian Nationalism, Albania, Albanian Newspaper 


\section{Ailesi ve Ĕgitimi}

Asıl adı, İbrahim Mehmet Naci Sipahi (Spahiu) olan Derviş Hima, Ohri gölünün kıyı kasabalarından biri olan Struga'da 1872 yılında doğmuştur. Babası Maksud Naci Sipahi (Maksud Naxhi Spahiu) bölgenin önde gelen toprak sahiplerinden biriydi. ${ }^{1}$

İlköğrenimini kendi memleketinde tamamladıktan sonra Manastır'da rüştiye, Selanik'te idadi eğitimini tamamlamıştır. İstanbul'a gelerek Mekteb-i Tıbbiyye-i Şahanede eğitim almaya başlamıştır. Hemşerisi İbrahim Temo'nun kurucuları arasında bulunduğu İttihad-ı Osmanî Cemiyetiyle Jön Türklere katılırken bir yandan da Arnavutluk'un geleceğine kafa yormaya başlamışırı. ${ }^{2}$

Jön Türklere katılarak birtakım siyasî faaliyetlerin içerisinde bulunmaya başlayan Derviş Hima, ${ }^{3}$ söz konusu faaliyetleri nedeniyle ceza almaktan kurtulamamıştır. Mekteb-i Tıbbiyyedeki öğrenciliği esnasında kısa da olsa bir müddet Genç Osman'ın katledildiği Yedikule zindanlarına hapsedilmiştir. Altı arkadaşıyla birlikte kaldıkları bu karanlık zindanda onları en fazla tedirgin eden etrafta dolaşan akrepler olmuştur. Akreplere karşı sırayla uyuyarak çözüm bulmuşlarsa da zindanın rutubetine çözüm bulmak mümkün olmamış ve her sabah suya bastırılmışçasına sırılsıklam elbiselerle uyanmışlardır. Hatta yaşadıkları bu ağır koşullar karşısında daha fazla dayanamayan Kabasakallı Halid Efendi isimli arkadaşı rahatsızlanarak bir müddet sonra vefat etmiştir. ${ }^{4}$

1895 yılında Mekteb-i Tıbbiyyedeki eğitimini tamamlamadan İstanbul'dan ayrılan Derviş Hima, genç yaşına rağmen Arnavutluk'a giderek bölgeyi ve Arnavutları daha yakından tanımaya çalışmıştır. Hoca, kiracı, derviş ve tüccar kıyafetinde Arnavutluk'u baştan aşağı gezmiş; bir yandan bölgenin ileri gelen beyleri, ağaları ve tüccarlarıyla görüşürken bir yandan da köylüleri ziyaret ederek onların yaşantılarını tetkik ve mütalaa etmiştir. Kosova, İşkodra, Manastır ve Yanya valiliklerince hakkında yürütülen takibata rağmen Arnavutluk'un kuzeyini de ziyaret etmiştir. ${ }^{5}$ Özellikle Dıraç'taki faaliyetleri neticesinde Jön Türk hareketi için önemli miktarda bağış toplanmasını ve burada küçük bir teşekkül oluşmasını sağlamıştır ${ }^{6}$. Arnavutluk coğrafyasındaki şehirlerin neredeyse tümünü gezmiş; gittiği yerlerde toplantılar yapmış, küçük okullar açmış, bazı broşür ve gazetelerin yayınlanmasını sağlamıştır. Üzerindeki yoğun baskıya daha fazla tahammül edemeyerek 1897 yılının ortalarına doğru Romanya'nın başkenti Bükreş'e kaçmak zorunda kalmıştır.

\section{Yurtdışındaki Faaliyetleri}

Romanya'nın başkenti Bükreş'e yerleşen genç Derviş Hima, İstanbul'dan kaçarak yarım bıraktığı tıp eğitimini sürdürmek için Bükreş Üniversitesi Tıp Fakültesine kaydını yaptırmıştır. Ancak eğitimini tamamlaması hiçbir zaman mümkün olmamıştır. ${ }^{8}$ Kısa süre içerisinde

\footnotetext{
${ }^{1}$ Hasan Kaleshi, "Hima, Dervish”, Biographisches Lexikon zur Geschichte Südosteuropas. Bd. 2. Hgg. Mathias Bernath, Felix von Schroeder, München 1976, s. 161.

${ }^{2}$ Kaleshi, age., s. 161.

${ }^{3}$ Robert Elsie, "Hima, Dervish (1873-13 April 1928)", Historical Dictionary of Albania, 2nd ed., The Scarecrow Press, Lanham 2010, s. 191.

${ }_{5}^{4}$ Derviş Hima, Makber-i Ahrar, Roma 1901, s. 13-14.

5 "Derviș Hima ve Tasvir-i Efkâr", Arnavut, Nu: 15, 9 Nisan 1326 (22 Nisan 1909), s. 1-2.

${ }^{6}$ M. Şükrü Hanioğlu, Bir Siyasal Örgüt Olarak Osmanlı İttihad ve Terakki Cemiyeti ve Jön Türklük (1889-1902), İletişim Yay, İstanbul 1985, s. 302.

${ }^{7}$ Kaleshi, agm., s. 161.

${ }^{8}$ Kaleshi, agm., s. 161.
} 
buradaki başta İbrahim Temo olmak üzere Jön Türkler ve Arnavut diasporasıyla ${ }^{9}$ kaynaşan Hima, daha çok siyasî ve kültürel faaliyetlerin içerisinde yer almıştır. ${ }^{10}$ Hemşerisi İbrahim Temo, Bükreş ve Dobruca'daki faaliyetlerinden dolayı ondan övgüyle bahsetmiştir. ${ }^{11} \mathrm{Bu}$ dönemde İbrahim Temo ile yakınlaşan Derviş Hima, hayatı boyunca onunla irtibatını kesmemiş, her başı sıkıştığında ona müracaat etmiştir. İbrahim Temo'ya yazdığı mektuplarında ona "azizim, şeyhim, ya şeyh" şeklinde hitap etmiştir. Ayrıca bu mektupları üzerinden yapılan bir araştırmada Temo'nun onun "fikir babası, kasası ve bir numaralı destekçisi" olduğu kanaatine ulaşılmıştır. ${ }^{12}$

1898 yılında Bükreş’te "Pavaresia e Shqipërisë (Arnavut Bağımsızlı̆̆ı)" adıyla Arnavutça, Fransızca ve Rumence yayınlanan bir gazete çıkarmaya başlamıştır. Ancak gazete çok kısa bir müddet sonra kapanmıştır. Bu dönemde Hima, Jön Türklerle bazı fikir ayrılıkları yaşamaya başlamıştır. Bunun ilk işaretleri 1899 yılında Brindisi'de yapılmaya çalışılan ancak akamete uğrayan kongredir. ${ }^{13}$ Kongrenin hazırlık çalışmaları devam ederken Cenevre'de Tunalı Hilmi'ye hitaben bir mektup kaleme almıştır. Ahmed Bedevi Kuran'ın son cümlesini oldukça manidar bulduğu mektup şu şekildedir:

\section{“Aziz kardeşim Hilmi;}

Cenevre'de çıkan "Intikam” gazetesi muntazaman bendenize geliyor. Gazete şu cebbar-ı mütekebbire karşı şiddetini artırmalıdır. Muhtelif komitelerin İstanbul'a yüklerle dinamit nakletmek yolların taharri ettiklerini havadis kabilinden yazınız... "Intikam" yalnız feryat mı edecek, yoksa icraat-ı ciddiyeye de başlayacak mı?

Yeni Osmanlılar Kongresinin bazı noktaları bizim için bir parça tuhaftır. Ehl-i İdrake az sözle çok şey ifham etmek tabiî olduğu cihetle bu kadarla hatm-i güftar eylerim."

\section{Derviş Hima - Naci ${ }^{14}$}

Öyle anlaşılıyor ki Derviş Hima, Abdülhamid'e karşı sadece basın yayın yoluyla muhalefet ederek devrim yapmanın mümkün olmadığına; kültürel faaliyetlerin yanı sıra silahlı unsurların da devrime katkı sağlaması gerektiğine inanıyordu. Zaten 1902 Birinci Jön Türk Kongresinde İsmail Kemal tarafından ortaya atılan bu fikre karşı çıkan olmamış ve kısa bir müddet sonra bu yönde girişimlerde bulunulmuştur. ${ }^{15}$

Derviş Hima, 1899 yılında Bükreş’teki Arnavutların katılacağ 1 bir kongre düzenlemek için çalışmalar yapmaya başlamıştır. Bu doğrultuda 31 Temmuz 1899'da Gazeteci Georges C. Mexi, Kigalık Müslüman Arnavutları Vekili Yaşar Sadık Erebera (Iachar Sadik Erebara) ve

${ }^{9}$ Romanya'daki Arnavut diasporasının çeşitli faaliyetleri hakkında bkz. Said Olgun, "Contributions Albanian Diaspora in Romania to the Development of Albanian Nationalism in the Last Quarter of Nineteenth Century", Glimpses of Balkan Cultural History, Ed. Abidin Temizer, Gece Kitaplı̆̆ı, Ankara 2017, ss. 27-42.

${ }^{10} 1897$ yılında II. Abdülhamid, baş hafiyesi Ahmet Celaleddin Paşa vasıtasıyla Jön Türklerle anlaşmaya çalışırken Cenevre Şubesi tarafından "Romanya'da Dobruca Kıtası İttihad ve Terakki Fırkası Riyaset-i Aliyyesine" hitaben yazılan bir mektupla buradaki Jön Türkler konudan haberdar edilmişlerdir. 7 Temmuz 1897'de söz konusu mektuba verilen cevapta imzası bulunanlardan biri de Derviş Hima olmuştur. Romanya'daki komite Abdülhamid'le barış sağlanabilmesi için bazı şartlar koşmuştur. Ahmet Bedevi Kuran, Osmanlı İmpatorluğunda Inkılâp Hareketleri ve Millî Mücadele, Türkiye İş Bankası Kültür Yay., İstanbul 2012, s. 201-202.

${ }^{11}$ İbrahim Temo, İttihad ve Terakki Cemiyetinin Teşekkülü ve Hidemat-1 Vataniye ve İnkılâb-1 Milliye Dair Hatıratım, Biz İttihatçılar, Yay. Haz. Nurer Uğurlu, Örgün Yay., İstanbul Haziran 2009, s. 139.

${ }^{12}$ Yunus Özgen, Mustafa Balcı, "II. Meşrutiyete Giden Yolda İbrahim Temo - Derviş Hima Mektuplaşması”, Türk Yurdu, Y11: 97, S. 251 (Temmuz 2008), s. 116.

${ }^{13}$ Kaleshi, agm, s. 161.

${ }^{14}$ Kuran, Osmanlı İmparatorluğunda ..., s. 251

${ }^{15}$ Sina Akşin, Jön Türkler ve İttihat ve Terakki, İmge Yay., 6. Bask1, İstanbul 2011, s. 83. 
Kigalık Müslüman Arnavutları Merkez Komitesi Vekili Derviş Hima'nın imzalarını taşıyan bir davetname yayınlamışlardır. "Arnavut Kardeşlerimizi Davet" başlığıyla yayımlanan davet metninde Avrupa'da hiçbir milletin Arnavutlar kadar "şayan-ı teessüf” bir halde bulunmadığı; memleketlerinde annelerinin, babalarının ve çocuklarının esaret altında figan ettikleri; can ve mal güvenliklerinin bulunmadığı ve Osmanlı Devletinin ciddi bir idareyi icra etmekten aciz olduğu ifade edilerek vatanın selameti için her türlü fedakârlıktan geri durmamaları gerektiği ifade edilerek İtalya, Yunanistan, Bulgaristan ve Misır'daki Arnavutlar da dâhil olmak üzere tüm Arnavutları 27 Eylül 1899'da Bükreş’te düzenleyecekleri kongreye davet etmişlerdir. ${ }^{16}$

Derviş Hima ve arkadaşları, davetiye olarak hazırladıkları broşürde şu sekiz talepte bulunmuşlardır: Padişaha bağlı olmak üzere Arnavutluk'a istiklalinin verilmesi; Arnavut millî mekteplerinin açılması; Müslüman, Katolik ve Ortodokslardan meydana gelen askerî bir birliğin oluşturulması; Arnavutluk'un büyük devletler tarafından seçilen padişah tarafından onanan bir vali tarafından yönetilmesi; ülkeden kaçanların affedilmesi; genel bir meclisin oluşturulması; Arnavutluk'a has bir bütçenin oluşturulması; Arnavutça ve Türkçenin resmî dil olarak kabul edilmesi. Otonomi talebinde bulundukları bu davet metni ile kongrenin gündemini de belirlemiş olan Derviş Hima ve arkadaşları, taleplerini Avrupa ülkelerinin hükümetlerine de göndermekten geri durmamışlardır. ${ }^{17}$ Osmanlı hükümeti, kongrenin 3 Ağustos 1878'de Prizren'de alınan kararları hayata geçirmek ve bu doğrultuda Avrupa ülkeleri nezdinde girişimlerde bulunulacağını öğrenmesi üzerine Romanya'daki Arnavut komitesiyle irtibatlı olduğu düşünülen kişilere pasaport verilmesini yasaklayarak kongreye katılımları engellemeye çalışmıştır. Öte yandan Bükreş’teki Osmanlı sefiri de Romanya hükümeti nezdinde girişimlerde bulunarak düzenleyicilerinin sınır dışına çıkarılması ve böylece kongrenin engellenmesi için gayret göstermiştir. ${ }^{18}$ Öyle ki hükümet, 30 Ağustos 1899 'da Posta ve Telgraf Nezareti, Zabtiye Nezareti ve vilayetlerden Derviş Hima ve arkadaşları tarafindan gönderilen evrakın ülkeye girişine izin verilmemesini ve eğer varsa dağıtımının engellenmesi istenmiştir. $^{19}$

Derviş Hima, Arnavut komitesinin fikir ve ideolojilerini anlatabileceği tüm firsat ve imkânları değerlendirmiştir. 1899 yılında Roma'da on ikincisi düzenlenen Uluslararası Oryantalistler Kongresi'ne Bükreş'ten katılan Derviş Hima, burada Arnavut komitesinin fikir, ideoloji, faaliyetlerini yaymaya çalışmış ve bu yönde telkinlerde bulunarak akademik camiada bir kamuoyu oluşturmaya çalışmıştır. ${ }^{20}$

Derviş Hima'nın faaliyetlerinden rahatsız olan Osmanlı hükümeti, Romanya hükümeti nezdinde girişimlerde bulunarak Ekim 1899'da oturma izninin iptal edilmesini sağlamıştır. Romanya'yı terk etmek zorunda kalan Derviş Hima, İtalya'ya yerleşerek siyasî faaliyetlerini buradan yürütmeye başlamıştır. Roma'da bulunduğu süre boyunca çok ciddi bir yayıncılık faaliyetine girişerek Mehmed Bey Frasheri ile birlikte Arnavutça ve Fransızca yayınlanan "Zëni $i$ Shqipërisë (L'écho d'Albanie, Arnavutluk'un Sadası) isimli gazeteyi çıkarmaya başlamıştır. Gazetenin ilk nüshasından itibaren otonom bir Arnavutluk'un kurulmasını savunmuşlardır. Mehmed Frasheri'nin İstanbul'a dönmesi üzerine gazeteyi devralarak adını "Albania (Arnavutluk)" olarak değiştiren Derviş Hima, gazete yayıncılığının yanı sıra arka

\footnotetext{
${ }^{16}$ Devlet Arşivleri Başkanlığı-Osmanlı Arşivi (DAB-OA), Hariciye Nezareti Siyasî (HR.SYS), 129/25, 28 Ekim 1899. Mithat Aydın, "Bükreş’te Komitacılık Faaliyetleri, (1860-1916)", Çağdaş Türkiye Tarihi Araştırmaları Dergisi, C. 15, S. 30 (2015/Bahar), s. 27-28.

${ }^{17}$ DAB-OA, HR.SYS, 129/25, 28 Ekim 1899.

${ }^{18}$ Olgun, agm., s. 36-37.

${ }^{19}$ DAB-OA, Dahiliye Nezareti Mektubi Kalemi (DH.MKT), 2240/37, Hicrî (H.) 21.04.1317 (29 Ağustos 1899).

20 DAB-OA, HR.SYS, 129/24, 13 Ekim 1899. DAB-OA, Yıldız Sadâret Hususî Maruzât Evrakı (Y.A.HUS), 400/104, H. 09.06.1317 (15 Ekim 1899).
} 
arkaya bir dizi risaleler yayınlamıştır. ${ }^{21}$ Osmanlı hükümetinin İtalya hükümeti nezdindeki girişimleri neticesinde 1902 yılının şubat ayında Arnavutluk gazetesinin Roma'daki yayın faaliyeti durdurulmuştur. ${ }^{22}$

Derviş Hima, Roma'da bulunduğu günlerde Jön Türk hareketinin önemli isimlerinde İshak Sükûtî ile oldukça yakınlaşmıştır. Öyle ki İshak Sükûtî, kitaplarını ve İttihat Terakki ile ilgili çok önemli evraklarını ona emanet etmiştir. Verem hastası olan İshak Sükûtî, San Remo'dan Derviş Hima'ya yazdığı mektuplarda “yakında behemehâl öleceğim evrakı Temo'ya göndereceğim" diyerek 1srarla belgelerin kendisine gönderilmesini istemiştir. Sükûtî, Derviş Hima'nın gönderdiği evrakları teslim aldıktan iki gün sonra, İbrahim Temo'ya gönderemeden, 9 Şubat 1902'de vefat etmiştir. San Remo konsolosu Resul Efendi'nin eline geçen evraklar, ayıklanarak imha edildikten sonraya geriye kalan önemsiz kısmı Yıldız'a gönderilmiş böylece birçok kişinin tutuklanmaktan ve felakete uğramaktan kurtulmuşlardır. ${ }^{23}$

Sefarethaneler aracılığıyla gittiği ülkelerde çok sıkı bir şekilde takip edilen Derviş Hima, Osmanlı hükümetinin nefesini ensesinde hissetmekten kurtulamamıştır. 1901 yılının ilk aylarında Roma Sefareti, girişimde bulunarak İtalya hükümeti tarafından uyarılmasını sağlamıștır. İtalya hükümeti onu rahat durması aksi takdirde tard ve tedip edileceği yönünde ikaz etmiştir. ${ }^{24}$ Ancak iş bununla kalmamıştır. Derviş Hima'nın bir yandan yayıncılık faaliyetleriyle Abdülhamid'e karşı çok sıkı bir muhalefet yürütmesi bir yanda da buradan Paris’te yaşayan Prens Gjin Aladro Kastriota (Don Juan Aladro Perez de Velasco) ${ }^{25}$ ile işbirliği içerisinde Arnavutluk'ta karışıklık çıkarmaya yönelik faaliyetlerde bulunması Osmanlı sefaretini ona karşı İtalya hükümeti nezdinde girişimlerde bulunarak bir takım tedbirler almaya sevk etmiştir. Roma Sefirinin teşebbüsleri neticesinde 3 Haziran 1901'de İtalya'dan kovulmasına karar verilmiştir. İtalyan hükümeti tarafından ülkeden çıkarılmasına karar verilen Derviş Hima, şüpheli bakışlardan ve takipten kurtulamamıştır. Roma sefareti, ele geçirdiği iki mektuptaki yazışmalardan hareketle onun Paris'e giderek Prens Kastriota ile buluşacağ 1 ve Arnavutluk'ta kargaşa çıkarmaya yönelik faaliyetlerde bulunacağından şüphelenmektedir. Hariciye Nezareti, Roma sefaretinin uyarılarını dikkate alarak; ${ }^{26}$ Paris Sefaretinden Derviş Hima'nın takibini istemiştir. ${ }^{27}$

Bükreş'e dönen Derviş Hima, 4 Şubat 1902'de Paris'te Prens Sabahaddin'in öncülüğünde toplanan Birinci Jön Türk Kongresine katılmıştır. Osmanlı İmparatorluğu'nu oluşturan hemen hemen bütün unsurların temsil edildiği bu kongreye Jön Türklerin ve Abdülhamid muhaliflerinin en tanınmış simalarından yetmiş̧e yakın isim katılmıştır. Kongreye Derviş Hima'nın yanı sıra, İbrahim Temo, İsmail Kemal, Hoca Kadri ve Yaşar Erebera gibi Arnavut muhalifler ile Jön Türklerin önemli simalarından Sabahattin ve Lütfullah Bey, Ahmet Riza,

\footnotetext{
${ }^{21}$ Kaleshi, agm., s. 161.

22 DAB-OA, Yıldız Perakende Evrakı Elçilik, Şehbenderlik ve Ateşemiliterlik Maruzâtı (Y.PRK.EŞA), 39/64, 04.11.1319 (12 Şubat 1902).

${ }^{23}$ Riza Nur, "San Remo'da İshak Sükûtî”, Şehbâl, Nu: 15, 1 Teşrinisani 1325 (14 Kasım 1909), s. 291. Ayrıca bkz. Ahmet Kanlıdere, "İttihat ve Terakki’nin Gölgede Kalmış Simalarından Doktor İshak Sükûtî (1868-1902)", Tarihçiliğe Adanmış Bir Ömür Prof. Dr. Nejat Göyünç'e Armağan, Ed. Hasan Bahar vd., Selçuk Üniversitesi Yay., Eylül 2013 İstanbul, s. 211.

${ }^{24}$ DAB-OA, HR.SYS, 1809/47, 7 Mart 1901.

${ }^{25}$ Don Aladro Kastriota, İspanyol asıllı olmasına rağmen, atalarından biri Napoli'de Kastriota ailesinden Marchesa Auletta isimli bir kızla evlendiği için İskender Bey'in soyundan geldiğini iddia ederek çeşitli faaliyetlerde bulunmuştur. Arnavut meselesine ilgi uyandıran propagandası nedeniyle birçok Arnavut'un sempatisini kazanmıştır. Avlonyalı Ekrem Bey, Osmanlı Arnavutluk'undan Anılar (1885-1912), çev. Atilla Dirim, İletişim Yay., İstanbul 2006, S. 67

${ }^{26}$ DAB-OA, Y.PRK.ESA, 40/43, H. 26.02.1320 (4 Haziran 1902). DAB-OA, HR.SYS, 117/55, 6 Haziran 1902.

${ }^{27}$ DAB-OA, Y.A.HUS, 429/116, H. 27.02.1320 (5 Haziran 1902).
} 
Halil Ganem, Yusuf Akçura, Hüseyin Siret, Doktor Nazım katılmışlardır. ${ }^{28}$ Arnavutların oldukça geniş bir şekilde temsil edildiği görülen kongreye İtalya Arnavutlarını temsilen katılan Derviş Hima, Arnavutçanın Latin harfleriyle yazılması yönündeki telkin ve teşvikleri nedeniyle Jön Türklerin milliyetçi kanadı tarafından tenkit edilmiştir. ${ }^{29}$

Tam bir örgütçü olarak nitelendirilen Derviş Hima, 1902 yılının Mayıs ayındaki ilk İsviçre seyahatinde çeşitli milliyetçi gruplar ile Osmanlı reformistleri arasında geniş bir haberleşme ağı kurmuştur. Birçok arkadaşı gibi Arnavutçanın resmî dil olarak kullanılmasını ve Arnavutluk'a özerklik verilmesini talep ederken Osmanlı Devleti'nin parçalanmasını istemiyordu. Bu doğrultuda İttihat Terakkinin ve yapılması gereken reformların yılmaz bir savunucusu haline gelmiştir. Hima'nın çelişik görülen bu ideolojisi İsviçre'deki Arnavut topluluğunun önemli isimleri tarafından da desteklenmiştir. 1902-1904 yılları arasında on beş aydan daha uzun bir süre kaldığı İsviçre'de özellikle Lozan ve Cenevre'de bulunmuştur. İttihat Terakki'nin Avrupa'daki faaliyetlerini desteklemeye başlayan muhalif gruplarla yakın bir bağ kurabilmek için burada ikamet eden aktivistlerle yakınlaşmıştır. İdeolojik alt yapısını oluşturan İttihat Terakki vasıtasıyla Arnavutları organize ederek Arnavutluk hakkında bir takım endişeler taşıyan büyük devletler nezdinde lobi faaliyetlerinde bulunmalarını sağlamıştır. Avrupa ülkelerinin politikalarını etkilemeye yönelik İttihat Terakki ve Arnavutlar arasında kurulan birliktelik İsviçre'ye gelen Arnavutlar arasında ilginç ilişkilerin kurulmasını sağlamıştır. Bunlardan en dikkat çekicisi sık sık İskender Bey'in soyundan geldiğini dile getiren İspanya doğumlu diplomat ve siyasî spekülatör Prens Kastriota olmuştur. Her ne kadar Kastriota tarihsel açıdan çok önemli bir yere sahip değilse de Rusya, İngiltere ve Avusturya'nın temsil edildiği geniş çaplı gayri resmî diplomatik temasların kurulmasını sağlamıştır. ${ }^{30}$ Osmanlı belgelerinde "din ü devlet ve vatana muhabbeti olmayan ve harekâtmefsedetkaraneleriyle ne derece hain olduklarını bizzat ispat" eden kişiler olarak nitelendirilen İsmail Kemal ve Derviş Hima, öteden beri Kastriota ile temas içerisinde bulunmuşlar ve Osmanlı hükümeti bu ilișkiyi takibe almıştır. Osmanlı hükümetinin bu ilişki hakkındaki kanaati, bu iki ismin Kastriota'nın servet ve mizacından istifade ederek Arnavutlar arasında çıkarmak istedikleri kargaşaya alet ettikleri yönünde olmuştur. ${ }^{31}$

Büyük güçler, Sırplar, Bulgarlar ve Yunanlılar arasında yaşanan Makedonya krizini çözmeye çalışırken İsviçre'deki Arnavutlar üzerinde ciddi bir etkiye sahip olan Derviş Hima'ya ve onunla birlikte İttihat Terakkiye ilgi göstermeye başlamışlardır. Derviş Hima, hem Avrupa ülkelerinin Makedonya'ya yönelik politikalarını etkilemek hem de Avrupa'da yaşayan Arnavutlara fikri telkinde bulunmak için Albania (Arnavutluk) gazetesini tekrar yayınlamaya başlamıştır. 1903 yılının Eylül ayında yayın hayatına başlayan gazete, Fransızca, Arnavutça ve Türkçe olarak haftalık yayınlanmıştır. Derviş Hima, gazete için Avusturya'nın Bern Büyükelçiliğinden sağladığı finansmanı devam ettirmek için Manastır'daki Avusturya Konsolosu August Ritter Von Kral ile olan yakın ilişkisini kullanmıştır. Geniş bir okuyucu kitlesine ulaşan gazete, Avrupa'da Jön Türkler tarafından çıkarılan birçok yayını etkilemiş ve iki yıl sonra yayın hayatına veda etmiştir. Hima'nın gazetede yer verdiği düşünceler, her

\footnotetext{
${ }^{28}$ Ahmet Bedevî Kuran, Inkılap Tarihimiz ve Jön Türkler, Kaynak Yay., 2. Baskı, İstanbul Nisan 2000, s. 189-190. Stavro Skendi, The Albanian National Awakening 1878-1912, Princeton University Press, New Jersey 1967, s. 336. M. Şükrü Hanioğlu, Derviş Hima’yı Jön Türklerin önde gelenleri arasında sayar. Şükrü Hanioğlu, "Jön Türkler", Türkiye Diyanet Vakfi İslam Ansiklopedisi, C. 23, İstanbul 2001, s. 586.

${ }^{29}$ M. Şükrü Hanioğlu, The Young Turks in Opposition, Oxford University Press, Oxford-New York 1995, s. 182.

${ }^{30}$ İsa Blumi, Publishers, Hitmen, Diplomats, and Dreamers: Switzerland's Ottoman-Albanian Diaspora, 1899-1920, Schweizerische Zeitschrift für Geschichte $=$ Revue suisse d'histoire = Rivista storica svizzera, Volume 52 (2002), s. 313-315.

${ }^{31}$ DAB-OA, Sadâret Mektubî Kalemi Mühimme Kalemi Belgeleri (A.MKT.MHM), 730/10, H. 10.01.1321 (8 Nisan 1903).
} 
zaman Arnavutlar tarafından kabul görmemiştir. Özellikle Arnavutluk'un bağımsızlı̆̆ı düşüncesi Osmanlı milletinin parçalanmasına yol açacağı; Yunan ve Slav yayılmacıllı̆̆na hizmet edeceği gerekçesiyle karşı çıkışı, ayrılıkçı Arnavutları oldukça kızdırmıştır. ${ }^{32}$

Derviş Hima, Cenevre'de bulunduğu dönemde, yapılan davet üzerine, 13-15 Haziran 1903'te Napoli'de düzenlenen Arnavut Kongresine Arnavutluk gazetesini temsilen katılmıştır. ${ }^{33}$ Osmanlı Devletinin Napoli'deki Başşehbenderinin ifadesine göre kongreye katılan tek Müslüman Arnavut Derviş Hima'dır. Kongrede Osmanlı Devletinden kovulan, sürülen, tutuklanan ve hapis cezasına çarptırılanların suçlarının affedilmesi ve tahliyesi için İtalya hükümetinden aracılık yapmasının talep edilmesine karar verilmiştir. Roma Sefiri Reşid Beyin girişimleriyle gazetelerin konferansa ilgi göstermesi engellenmiş; konuyu ele alanlar da yüzeysel haberlerle geçiştirmişlerdir. Böylece kongrenin kamuoyunun dikkatini çekmesi

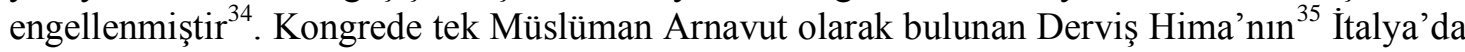
uzun süre durması mümkün olmamıştır. Roma'daki Türk Sefiri Reşid Beyin girişimleri neticesinde 23 Haziran 1903'te İtalyan hükümeti tarafından gözaltına alınarak sınır dışı edilmiştir ${ }^{36}$.

Öyle ki Roma seferi ilk kez 1901'de İtalya'dan çıkarılmasını sağladığı Derviş Hima'nın son kez sınır dışı edilmesinden sonra 1903 Eylülünde İstanbul'a gönderdiği bir yazısında onun gidişinden sonra artık orada zararlı yayınların yapılmadığını belirtmiştir. ${ }^{37}$ Derviş Hima, kendisine İtalya'da kalma firsatı vermeyen Reşid Beye kaşı çok kızgındır; onu "alçak", "koyun beyinli" gibi ifadelerle tahkir etmiş ve Arnavutluk tarihinde adının lanetlenerek yâd edileceğini ifade etmiştir. İtalyan hükümetinin onun telkinleriyle hareket etmiş olması da onu büyük bir hayal kırıklığına uğratmıştır. Ona göre her taraftan bir darbe vurulan Arnavutluk'a bu kez de Adriyatik kıyılarından bir darbe vurulmak istenmiştir. ${ }^{38} 1902$ 'den beri İtalyanların himayesini arayan Derviş Hima' ya ${ }^{39}$ tüm bu yaşadıkları oldukça ağır gelmiş olmalı.

Tekrar Cenevre'ye dönen Derviş Hima, Arnavutluk gazetesini çıkararak yayıncılık faaliyetlerini sürdürmüştür. Sadr-ı Esbak Merhum Rifat Paşa'nın Mahdumu Cavid Bey Merhumun Sebeb-i Mevti Olan Ikinci Layiha isimli risaleyi burada kaleme alarak yayınlamıştır. Prens Albert G. Gika ve Faik Koniça'nın telkinleriyle 1904 yılında Londra'da düzenlenen Ermeni-Makedon Kongresine katılmıştır. Kongrede Arnavutların taleplerini dile getirmiş; Osmanlı Devletinde yaşayan diğer unsurlarla işbirliği yapabilecekleri yönünde iyi niyetini ifade etmiştir. Ancak ilerleyen süre içerisinde kongrenin Bulgarlar tarafından devrimci terörist amaçlarla tertiplendiğini gören Derviş Hima, kongredeki çalışmalardan çekilmiştir. 1908 yılına kadar Cenevre'de kalmış ve L'Albanie (Arnavutluk) gazetesini yayınlamaya devam etmiştir. ${ }^{40}$

\section{II. Meşrutiyet Sonrası Faaliyetleri ve Arnavut Gazetesi}

Derviş Hima, Meşrutiyetin ikinci defa ilanıyla ülkeye geri dönme firsatı bulmuşsa da bir müddet sonra Jön Türklerle fikri olarak karşı karşıya gelmekten ve bunun neticesinde

\footnotetext{
${ }^{32}$ Blumi, agm., s. 313-315. Nathalie Clayer, Arnavut Milliyetçiliğinin Kökenleri Avrupa'da Çoğunluğu Müslüman Bir Ulusun Doğuşu, çev. Ali Berktay, 1. Baskı, Bilgi Üniversitesi Yay., İstanbul Haziran 2013, s. 322.

${ }^{33}$ Derviş Hima, Sadr-l Esbak Merhum Rifat Paşa'nın Mahdumu Cavid Bey Merhumun Sebeb-i Mevti Olan İkinci Layiha, Cenevre 20 Temmuz 1903, s. 2.

${ }^{34}$ DAB-OA, HR.SYS, 130/28, 25 Haziran 1903.

${ }^{35}$ DAB-OA, Y.A.HUS, 450/141, H. 30.03 .1321 (26 Haziran 1903).

${ }^{36}$ DAB-OA, HR.SYS, 155/22, 24 Haziran 1903. DAB-OA, Y.A.HUS, 450/136, H. 29.03.1321 (25 Haziran 1903).

${ }^{37}$ DAB-OA, HR.SYS, 1764/7, 13 Eylül 1903.

${ }^{38}$ Derviş Hima, Sadr-ı Esbak Merhum..., s. 2-5.

${ }^{39}$ Şerif Mardin, Jön Türklerin Siyasî Fikirleri 1895-1908, İletişim Yay., 18. Baskı, İstanbul 2012, s. 163.

${ }^{40}$ Kaleshi, agm., s. 162.
} 
tutuklanmaktan kurtulamamıştır. Arnavut coğrafyasında halka hitaben yaptığı coşkulu konuşmalarda Jön Türklerin savundukları Pan-İslamizm düşüncesine, Arnavutların millî birliğini savunarak karşı çıkmış ve özerklik yönünde bir takım ifadeler kullanmıştır. Söyledikleri Arnavut dinleyicilerde büyük bir heyecan oluştururken Jön Türkleri kızdırmış ve okların üzerine çevrilmesine neden olmuştur. Bunun neticesinde Derviş Hima, Jön Türklerce düzenlenen bir suikast girişiminden canını kurtarabilmiş ama hapse atılmaktan kurtulamamıştır. ${ }^{41}$ İşkodra hapishanesinde tutuklu bulunan Derviş Hima'ya uzun süre kaldığ Bükreş’teki arkadaşları sahip çıkmıştır. 11 Ekim 1908'de Bükreş'teki Arnavut Cemaati namına Andrey Aliluci (?) imzasıyla Sadarete gönderilen yazıda şu ifadelere yer verilmiştir:

"Karındaşlarımızdan ve tebaa-i Devlet-i Aliyyeden Derviş Hima, bir cani gibi üç aydan beri İşkodra hapishanesinde mevkuf tutulmaktadır. Derviş Hima taassup kurbanı olduğundan kendisinin tahliyesi hususunda evamir-i sami-i fehimaneleri ita buyurulmasını Kanun-i Esasi ve insaniyet namina istirham eder ve aksi takdirde bilcümle düvel kabinelerine bu ahval-i adaletşikenaneden dolayı protesto edeceğimizi beyan ederiz." ${ }^{42}$

Yaklaşık sekiz ay sonra serbest bırakılan Derviş Hima, ${ }^{43}$ Arnavutluk'ta yedi ay süren bir geziye çıkmış ve uğradığı yerlerdeki Arnavut kulüplerinde çeşitli konferanslar vermiştir. ${ }^{44}$ Derviş Hima'nın bu dönemdeki seyahatleri bir dizi konferanstan ibaret değildi. Gizli bir takım komitelerin kurulmasında faal olarak çalışmış; Manastır'a yaptığı seyahatler sonucunda Manastır'ın her bölgesinde gizli komiteler oluşturulmasını sağlamıştır. Bu çerçevede 18 Nisan 1909'da Elbasan'da başkanlığını Derviş Hima'nın yaptığı Vllazeria (Kardeşlik) adında bir cemiyet kurulmuştur. Cemiyetin görünürdeki amacı Arnavut dilinin yaygınlaştırılmasıyken esas amacı, Arnavutluk'ta yeni gizli komitelerin kuruluşunu teşvik etmekti. ${ }^{45}$ Yapmış olduğu konuşmalardan dolayı 1909 yılının Haziran ayında tekrar tutuklanma tehlikesiyle karşı karşıya kalmıştır. Öyle anlaşılıyor ki Arnavutluk'ta özerk bir yapı kurmak isteyen Derviş Hima, söylem ve eylemleriyle İşkodra valiliğini oldukça rahatsız etmiştir. Ancak bu kez daha temkinli hareket eden Hükümet, Dâhiliye Nezaretinden Derviş Hima'nın mevcut idare biçimini değiştirmek gibi teşebbüsünü ispatlayacak deliller varsa tutuklanarak mahkemeye sevk edilmesini ancak delil yoksa böyle bir fikre sahip olmadığ 1 yönündeki rivayetler de göz önünde bulundurularak, ihtiyat ve itidalle hareket edilmesini istemiştir. ${ }^{46}$ İttihat Terakki yönetimi, bu dönemde Derviş Hima'nın faaliyetlerinin önünü alabilmek için ona Tiflis şehbenderliği veya Kastamonu valiliği görevlerini teklif etmişse de her ikisini de reddetmiştir. ${ }^{47}$

Derviş Hima, 23-28 Temmuz 1909 tarihinde Debre'de gerçekleştirilen Debre Osmanlı Arnavut İttihat ve Meşrutiyet Kongresine katılmıştır ${ }^{48}$. Meşrutiyetin ilanının birinci yıl dönümünde gerçekleşen kongreye çok geniş bir katılım olmuştur. Kongre sonunda "Mevâd-1 İbtidâiyye-i İttihâdiyye" başlığı altında beş maddeden oluşan bir karar metni açıklanmıştır. Özellikle Osmanlılık kavramı üzerinde durulan karar metninde Osmanlı ve Meşrutiyet kelimelerinin yüceltilmesinin birinci vazifeleri olduğu, Osmanlı olarak ölme azminde

${ }^{41}$ Skendi, age., s. 363, 397. Banu İşlet Sönmez, II. Meşrutiyette Arnavut Muhalefeti, 1. Baskı, Yap1 Kredi Yay., İstanbul Nisan 2007, s. 139.

${ }^{42}$ DAB-OA, HR.SYS, 155/47, 11 Kasım 1908.

${ }^{43}$ Kaleshi, agm., s. 163.

${ }^{44}$ Derviş Hima, "Vatandaşlara İfademiz", Arnavut, Nu: 1, 31 Kânunuevvel 1325 (13 Ocak 1910), s. 1.

${ }^{45}$ Sönmez, age., s. 99.

${ }^{46}$ DAB-OA, DH.MKT, 2844/58, H. 26.05.1327 (15 Haziran 1909).

${ }^{47}$ Kaleshi, agm., s. 163.

${ }^{48}$ Clayer, age., s. 538. Olgun, age., s. 261. 
oldukları, meşrutiyet hükümetinin korunması için Arnavut askerlerinin hükümetin emrinde olduğu ifade edilmiştir. Samimiyetten ve gerçeklerden uzak bu kararların alındığg kongre, istenilen neticeyi vermediği gibi Arnavutça eğitim taleplerinin daha gür bir şekilde dile getirilmesini sağlamış ve Arnavutluk'un bağımsızlığını savunanları daha da gayrete getirmiştir ${ }^{49}$.

Derviş Hima, 18 Aralık 1909'da Köstece'den İstanbul'a gelerek Beyoğlu'nda Emperyal Oteline yerleşmiştir. ${ }^{50} \mathrm{Bu}$ tarihten sonra İstanbul'da yaşamaya başlamış ve en büyük meşguliyeti 13 Ocak 1910'da ilk sayısı yayınlanmaya başlayan Arnavut gazetesi olmuştur. Müdür ve imtiyaz sahipliğini Derviş Hima'nın yaptı̆̆ gazete, Arnavutlardan oluşan bir heyet tarafından idare edilmiştir. Haftalık olarak yayınlanan Arnavut, "Menafi-i Umumiyyeye Hâdim Hür ve Müstakildir" mottosuyla yayınlanmıştır. Dört sayfa olarak yayınlanan gazetenin iki sayfası Türkçe; iki sayfası ise Arnavutça yayınlanmıştır. İlk sayısında Derviş Hima tarafından kaleme alınan "Vatandaşlara Ifademiz" başlıklı yazıda gazetenin daha önce Avrupa'da yayınladığı "Arnavutluk" gazetesinin devamı niteliğinde olduğunu belirtmiştir. Gazetenin amacını "vatandaşlarımız" olarak ifade ettiği Arnavutları aydınlatmak, idrak ve irfanlarını yükseltmek, onlara "Osmanlı unsurları içinde kendi mevki-i mühimlerini anlatmak" olarak belirtmiştir. Derviş Hima, Arnavutların mühim bir mevkie sahip olduklarını ifade ederek onlara millî bir bilinç kazandırmaya çalışırken bir yandan da Osmanlılık fikri üzerinde durmuştur. Bu çerçevede “Biz ne bir Rum'un ne bir Bulgar'ın ne bir Sirp'ın ne bir Arap'ın veya Türk'ün veya Ermeni'nin Arnavut olmalarl fikrinde olmadığımızı her vakit samimiyetle ilan edip duruyoruz... Şovenizmden uzaklaşarak memleket-i müşterekimizi memalik-i mütemeddine derecesine yükseltmeye çalışırsak umum için hayırlı olur fikrindeyiz... Bizim de bir gazetemiz olursa zannedersek Osmanlılı̆̆ın ahenk-i umumi-i terakkisine bir rükn-i mühim ilave edilmiş olur..." 51 şeklindeki ifadeleriyle Osmanlılık kavramı üzerinde dururken gazetede yayımlanan imzasız bir yazıdaki "Arnavutlar, bu mülk ve memlekete en ziyade ve muhterem ve tarihî zekalar, vücutlar yetiştiren bir kavimdir. Tarih-i Osmani'nin en güzide, en ulvi, en ruhnevaz sayfalarında onların nesl-i şecaatlerinden, onların kanından, ruhundan kopmuş bir isme, büyük bir sadrazama, klymetli bir kumandana tesadüf ederiz. Sadrazam paşa hazretlerinin dedikleri gibi Arnavutlar tarih-i Osmaninin elmas-ldır..." ${ }^{, 2}$ ifadeleri de Arnavutların millî gururunu okşayan ve onlara millî bir bilinç kazandırmaya yönelik ifadelerdir.

Derviş Hima, Hile Mosi ve Avlonyalı Ekrem Bey'in yardımlarıyla çıkardığı Arnavut gazetesinde Arnavut dili, tarihi ve kültürü hakkında çok sayıda makale kaleme alarak Arnavutlar arasında millî bilincin gelişimine çok büyük katkı sağlamıştır. Gazetede en yoğun

\footnotetext{
${ }^{49}$ Faruk Ilıkan, "Debre Kongresi”, Simurg, Y11: 1, S. 1, Ekim 199, s. 200-201. Süleyman Külçe, Osmanlı Tarihinde Arnavutluk, İzmir 1944. s. 385. Derviş Hima, 2-8 Eylül 1909 tarihlerinde gerçekleştirilen Elbasan Arnavut Maarif Kongresi'ne katılmamıştır. Kongrenin toplanmasına önayak olan ve kongreye başkanlık eden kişi Derviş Biçaku'dur. Derviş Hima, Strugalı iken Derviş Biçaku Elbasanlıdır. Bundan dolayı Elbasan Kongresini ele alan çalışmalarda "Elbasanlı Derviş" ifadesi yaygın olarak kullanılmıştır. Ülkemizdeki değerli araştırmacıları gayriihtiyari olarak kongre başkanlığına Derviş Hima'nın getirildiğini ifade etmek zorunda bırakan ise 12 Eylül 1909 tarihli Yeni Tasvir-i Efkâr gazetesinin Osmanişer Loyd'dan aktardığı Derviş Hima’nın kongre başkanlığına getirildiği şeklindeki haberi olmuştur. "Arnavut Kongresi”, Yeni Tasvir-i Efkâr, Nu: 104, 12 Eylül 1909, s. 6 (2. Sütun). Çelik, age., s. 258. Ercan Karakoç, Mesut Yavaş, "İkinci Meşrutiyet Döneminde Arnavutların Eğitim Çalışmalarında Önemli Bir Aşama: Elbasan Maarif Kongresi”, Belleten, C. LXXXII, S. 249 (Ağustos 2018), s. 684, 690. Skendi, age., s. 271, 382. Sönmez, age., s. 140-141. Sokol Gjevori, "Educational and Cultural Traditions in Elbasan During the Nineteenth Century - 1912”, European Scientific Journal, Vol. 10, March 2011, s. 141.

${ }^{50}$ DAB-OA, Dahiliye Nezareti Emniyet-i Umumiye Tahrirat Kalemi Evrakı (DH.EUM.THR), 93/64, H. 16.12.1327 (29 Aralı 1909).

${ }^{51}$ Arnavut, Nu: 1, 31 Kânunuevvel 1325 (13 Ocak 1910), s. 1

52 “Arnavutluk Ahvâli”, Arnavut, Nu: 16, 15 Nisan 1326 (28 Nisan 1910), s. 1-2.
} 
şekilde üzerinde durduğu konu, Arnavutçanın Latin harfleriyle yazılması ve Arnavutçanın eğitim dili ve resmî dil haline getirilerek yaygınlaştırılması olmuştur. ${ }^{53}$

$\mathrm{Bu}$ dönemde Arnavut milliyetçileri, öne çıkan ve gelecek vadeden Jön Türkleri kendi yanlarına çekmek ve onları kazanmak için faaliyet gösterirken dikkatlerini çeken isimlerden biri Yarbay Mustafa Kemal olmuştur. Derviş Hima ve Avlonyalı Ekrem Bey, babasının Leskoviçli annesinin Pargalı birer Arnavut olduğunu iddia ettikleri Mustafa Kemal ile yakınlaşmak için ziyaretine gitmişlerdir. Arnavut milliyetçiliğine sıcak bakmayan Mustafa Kemal, Arnavutçanın Arap alfabesi dışında başka bir alfabeyle de yazılmasını Osmanlı birliğine zarar vereceği için uygun bulmamıştır. O günün şartlarında Arap alfabesini savunun Mustafa Kemal, yıkılan Osmanlı Devletinin yerine yeni bir millî devletin kuruluşuyla birlikte Türkçenin ses yapısına uygun olmayan Arap alfabesinin yerine yeni Türk alfabesine geçilmesini sağlamıştır. Avlonyalı Ekrem Beyin de ifade ettiği gibi Mustafa Kemal, 1934'te "Atatürk" soyadını alarak etnik kökeni hakkındaki tartışmaları tüm zamanlar için manasız hale getirmiştir. ${ }^{54}$

Derviş Hima, zaman zaman Üsküp ve Manastır'daki abonelerine gönderdiği gazete nüshalarının postanelerden alınarak abonelere dağıtılmadığından şikâyetçi olmuştur. ${ }^{55} \mathrm{Bu}$ durumu gazetesinin sütunlarına da taşımış dönemin Dâhiliye Nazırı Talat Paşa'ya daha önce posta memuru olduğunu hatırlatarak devr-i istibdatta bu tür olayların normal karşılandığını ancak meşrutiyet düzeni içerisinde bu olayların önünün alınması gerektiğini ifade etmiştir. ${ }^{56}$

Derviş Hima, İstanbul'da bulunduğu dönemde de sık1 bir şekilde takip edilmiştir. ${ }^{57}$ Arnavut gazetesi, 9 Eylül 1910 tarihli 29. sayısının Arnavutça yayımlanan "Shqipetari" nüshasında yer alan "Bir Garip Karar" başlıklı makalede gayrimüslim Osmanlı vatandaşlarına zarar verecek bir takım ifadelerin tespiti üzerine Divan-1 Harb-i Örfi kararıla 7 Ekim 1910'da tatil edilmiştir. ${ }^{58} 9$ Ekim'de yayınlanan 33. sayısıyla birlikte gazetenin yayın faaliyeti bir süreliğine durdurulmuştur. Ancak Derviş Hima, "sevgili vatandaşlarını mahrum-i havadis etmemek için 'Başkim' " isimli bir gazete çıkarmaya başlamıştır. Böylece Arnavut'un 34 ile 39. sayıları arasındaki altı sayısı Başkim adıyla yayınlanmış; yayın yasağının kalkmasından hemen sonra 13 Aralı 1910 tarihli 40. sayısıyla tekrar Arnavut adıyla yayınlanmaya devam etmiştir. $^{59}$

Derviş Hima, İstanbul'a geldikten sonra da zaman zaman Arnavutluk coğrafyasına ve Avrupa ülkelerine giderek siyasî faaliyetlerini sürdürmüştür. Bu çerçevede 1 Nisan 1910'da Manastır'da düzenlenen Arnavut Maarif Kongresine katılmıştır. İstanbul, Kosova, Manastır, Yanya, İşkodra ve Selanik Arnavut maarif kulüp ve cemiyetlerinin temsilcilerinden oluşan 25

\footnotetext{
53 “Arnavut Lisanı Hakkında”, Arnavut, Nu: 1, 31 Kânunuevvel 1325 (31 Ocak 1910), s. 2. "Arnavut Hurufatı", Arnavut, Nu: 2, 7 Kânunusani 1325 (20 Ocak 1910), s. 1. "Arnavutça Harfler Meselesi”, Arnavut, Nu: 4, 21 Kânunusani 1325 (3 Şubat 1910), s. 1. "Arnavut Hurufu, Hükümet Bitaraf Kalıyor”, Arnavut, Nu: 5, 28 Kânunusani 1325 (10 Şubat 1910), s. 1. "Arnavut Hurufu Meselesinde Gizli Noktalar”, Arnavut, Nu: 7, 11 Şubat 1325 (24 Şubat 1910), s. 1. "İpek Mebusu Bedri Beyin Nutku Münasebetiyle -Hurufat Meselesi- ", Arnavut, Nu: 13, 1 Nisan 1326 (14 Nisan 1910), s. 1-2. "Meclis-i Vükelanın Nazargahına", Arnavut, Nu: 20, 22 Mayıs 1326 (4 Haziran 1910), s. 1. "Lisan", Arnavut, Nu: 44, 25 Kânunuevvel 1326 (7 Ocak 1911), s. 1. George Gawrych, The Crescent and the Eagle: Ottoman Rule, Islam and the Albanians, 1874-1913, I.B. Tauris, New York 2006, s. 183-186.

${ }_{54}^{54}$ Avlonyalı Ekrem Bey, age., s. 258-259.

${ }^{55}$ DAB-OA, Dâhiliye Nezareti Muhaberat-1 Umumiye İdaresi Evrakı (DH.MUI), 97/21, H. 27.07.1328 (14 Ağustos 1909).

56 “Arnavut'un Muhterem Karileri”, Arnavut, Nu: 18, 6 Mayıs 1326 (19 May1s 1910), s. 2.

${ }^{57}$ DAB-OA, DH.EUM.THR, 38/64, H. 19.06.1328 (28 Haziran 1910). DAB-OA, DH.MUI, 80/30, H. 25.06 .1328 (4 Temmuz 1910).

${ }^{58}$ DAB-OA, DH.SYS, 57/4, H. 08.10.1328 (13 Ekim 1910).

59 “Arnavut'un İfadesi”, Arnavut, Nu: 40, 30 Teşrinisani 1326 (13 Aralık 1910), s. 1.
} 
delegenin katılımıyla gerçekleşen kongrede alınan kararlarda oldukça etkili olmuştur. ${ }^{60}$ Kongrede Haziran ayında geniş katılımlı ikinci kongre düzenlenmesi; Arnavutlar ile hükümet arasındaki ilişkileri takip edecek bir istişare heyetinin oluşturulması; Arnavutça için Latin alfabesinin kullanımının uygun olduğunun bir muhtıra ile Maarif Nezaretine bildirmesi; Rumların Ortodoks Arnavutlar üzerindeki propaganda faaliyetlerini akim bırakmak için tedbirler alınmasını sağlamak gibi kararlar alınmıştır. ${ }^{61}$

6 Şubat 1910'da İbrahim Temo tarafından kurulan Fırka-i İbad (Osmanlı Demokrat Fırkası)'1 destekleyen Derviş Hima, ${ }^{62} 1911$ yılının ikinci yarısını yurt dışında geçirerek Bükreş ve Viyana'da bulunmuştur. 1912 yılının ilk aylarında İstanbul'a dönmüş ve Arnavutluk'a giderek siyasi faaliyetlerini sürdürmüştür. ${ }^{63}$ Mart 1912 'de yapılan seçimlerde aktif olarak çalışmış Arnavut milliyetçilerin Mebusan Meclisinde temsili için yoğun bir gayret sarf etmiş; bu çerçevede Arnavutluk'taki şehirlerin tamamına yakınını gezmiştir. Ancak, İttihat Terakki'nin girişimleri neticesi İsmail Kemal ve Hasan Priştina gibi vekillerin tekrar seçilmesi mümkün olmamıştır. ${ }^{64}$

Yukarıda değindiğimiz üzere Derviş Hima'nın Meşrutiyet öncesi dönemde yürüttüğü çalışmalar Avusturya-Macaristan İmparatorluğu tarafindan desteklenmiştir. Meşrutiyetin ilanından sonra da Avusturya ile ilişkilerini sürdürmüştür. İlk olarak 1910 yılının Nisan ayında Avusturya temsilcisi tarafından açacağ 1 okulların finanse edilmesi ve çıkardığ gazetede yayımlanmak üzere makale gönderilmesi teklifinde bulunulurken; Ocak 1912'de bu kez Derviş Hima, gazetesinin finanse edilmesi ile Manastır, Yanya ve Kosova'ya yapacağı seyahatler için kendisine destek olunmasını talep etmiştir. ${ }^{65}$

1909, 1910 ve 1911 y1lındaki isyanlardan sonra 1912 yılının Nisan ayından itibaren Arnavutluk'ta tekrar isyanlar başlamıştır. ${ }^{66} 1912$ yılında yapılan "Sopalı Seçim", meclis çoğunluğunu ele geçiren İttihat Terakki'nin zaferiyle sonuçlanırken aralarında Hasan Priştina ve İsmail Kemal gibi isimlerin de bulunduğu Arnavut muhalifler meclis dışında kalmışlardır. Halkın kızgınlığına sebep olan seçim sonucuna ek olarak hükümetin yanlış uygulamaları, Arnavut reislerin ihtiras ve menfaatleri, Katolik Arnavutlara silah dağıtılırken Müslümanların ellerindeki silahların toplanması gibi nedenler halk arasındaki huzursuzluğun büyüyerek bir isyana dönüşmesini sağlamıştır. ${ }^{67}$

Arnavutluk bir yangın yerine dönerken Derviş Hima'nın kendi köşesine çekilerek yaşanan olayları uzaktan takip etmesi beklenemezdi. Ohri ve Manastır'da isyanı organize ederek başlatan Derviş Hima, ${ }^{68}$ Korfu'ya geçerek isyanın Arnavutluk'un güneyine yayılması için çalışmaya başlamıştır. Yunanistan'ın hâkimiyeti altındaki Korfu adası, Yanya'ya yakınlığının sağladığı stratejik avantajın bir sonucu olarak, Arnavut muhalifler için güvenli bir liman haline gelmiştir. Bunun yanı sıra Arnavutluk'un muhtelif bölgelerine silah sevkiyatı da ada üzerinden gerçekleştirilmekteydi. Adanın hemen yanı başındaki Yanya vilayetinin dolayısıyla

${ }^{60}$ Clayer, age., s. 491. Said Olgun, Arnavut Milliyetçiliğinin Gelişiminde Mektepler, Gece Kitaplığı, Ankara 2016, s. $269-270$.

${ }^{61}$ Olgun, age., s. 270-271.

${ }^{62}$ Bilgin Çelik, İttihatçılar ve Arnavutlar, Büke Kitaplı̆̆ı, İstanbul Ağustos 2004, s. 127.

${ }^{63}$ Clayer, age., s. 538.

${ }^{64}$ Kaleshi, agm., 163. Özer Özbozdağlı, "Selanik, Manastır ve Kosova Vilayetlerinde 1912 Meclis-i Mebusan Seçimleri”, Gaziosmanpaşa Üniversitesi Sosyal Bilimler Araştırmaları Dergisi, C. 11, S. 2 (Kış 2016), s. 297.

${ }^{65}$ Clayer, age., s. 538.

66 Suat Zeyrek, "II. Meşrutiyet’te Demokratik Muhalefetin Sonu: Arnavut İsyanları Ve Sonuçları", Erciyes Üniversitesi Sosyal Bilimler Enstitüsü Dergisi, C. 1. S. 33 (2012/1), s. 299-306.

${ }^{67}$ Fahri Maden, “Arnavutluk’un Bağımsızlık Süreci (1877-1913)”, TIKA Avrasya Etüdleri, S. 38 (2011/1), s. 166169.

${ }^{68}$ Elsie, agm., s. 192. 
Arnavutluk'un asayiş ve güvenliğinin temininde burada görev Osmanlı şehbenderi birinci derecede etkiliydi. Bu gerçeğin farkında olan Yanya Valisi Mehmed Ali Bey, hükümetten bölgeye vukufu bulunmayan ve Rumca bilmeyen mevcut şehbenderin yerine Arnavutça, Rumca, Fransızca ve İtalyanca bilen bölgeyi tanıyan Avlonya Belediye Reisinin atanmasını tavsiye etmiştir. ${ }^{69}$

1912 yılının Mayıs ayında Korfu'da bir araya gelen Arnavutlar, Kosova'da olduğu gibi Yanya'da da bir ayaklanma başlatılmasına karar vermişlerdir. Kosova'daki ayaklanmaya Karadağ yardımcı olurken Yanya'dakine ise Yunanistan yardımcı olacaktı. Bu yardımlara karşılık olarak, bir kısım araziler Yunanistan ve Karadağ'a terk edilecekti. Alınan karara göre askerî birliklerin olmadığı yerlerde eşkıyalık faaliyetleri yürütülürken askerî birliklerin bulunduğu yerlerde memurlardan şikâyet edilerek Arnavutluk'un tamamında asayiş ve güvenlik bozulacaktı. Ortaya çıkan kaos ortamı, Avrupa devletlerine Arnavutluk'un kötü idare edildiği yönünde bir propaganda malzemesi olarak kullanılmak ve böylece onların müdahalesine zemin hazırlanmak istenmiştir. ${ }^{70}$

Alınan karar doğrultusunda bölgedeki asayiş ve güvenliği bozan, halkı Osmanlı Devleti'ne karşı kışkırtan ve onları bir ihtilale teşvik edenlerden biri de Derviş Hima'dır. İsmail Kemal tarafından Arnavutluk'un kuzeyinde başlayacak genel bir harekete Güney Arnavutluk'ta yaşayanların iştirak edip etmeyeceğini öğrenmek üzere görevlendirilmiştir. Avlonya, Delvine, Preveze'den sonra Filat'a gelmiş burada halka mevcut hükümet aleyhinde telkinlerde bulunduktan sonra ıslah heyetinin iş görmek şöyle dursun halkı aldattığını ifade ederek; Arnavutların ayaklanarak isyan etmelerini bir hak olarak nitelendirmiştir. ${ }^{71}$ Derviş Hima'nın aleni bir şekilde halkı ayaklanmaya teşvik etmesi üzerine Yanya Valiliği hızlı bir şekilde tutuklanarak İpek Divan-1 Harbine sevk edilmesine karar vermiştir. Ancak Derviş Hima, 10 Haziran 1912'de Preveze'den hareket ederek Dalmaçya'ya oradan da Korfu'ya dönmüş ve tutuklanmaktan kurtulmuştur. ${ }^{72}$

12 Haziran'da Korfu'ya ulaşan Derviş Hima, adaya gelip giden ve günlerce kalan Arnavutlarla sık sık görüşmeler yapmıştır. Onun adada bulunduğu günlerde Arnavutluk'tan gelip gidenlerin sayısında belirgin bir şekilde artış olmuş; birahane ve kahvehane gibi mekânlarda Derviş Hima'nın katılımıyla toplantılar yapılmıştır. Ara sıra uğradığı şehbenderlikte Arnavut gazetesine abone toplamak maksadıyla burada bulunduğunu, Yanya'ya gitmeyi düşündüğünü ancak tutuklanacağını öğrendiği için gitmekten vazgeçtiğini ifade etmiştir. $^{73}$ Derviş Hima, ülkenin muhtelif yerlerindeki Arnavut gençleri ve öğrencileri Korfu'da toplamaya başlamıştır. Arnavut gençlerinin adada toplanmasının ileride bir kalkışma için yapılan hazırlığın parçası olduğunu haber alan Yanya Valisi Mehmed Ali Bey, bazı tedbirler almaya çalışmıştır. Ancak devam eden Trablusgarp Savaşı nedeniyle sahil hattının baştanbaşa açık olması bu tedbirlerden bir sonuç alınmasını engelleyeceği için Korfu'da toplananların dağıtılması amacıyla Yunan hükümeti nezdinde diplomatik teşebbüste bulunulmasına karar verilmiştir. ${ }^{74}$ Nihayetinde Yunan hükümeti tarafindan Korfu'dan çıkarılmalarına karar verilen Derviş Hima ve 17 arkadaşı, bir sandalla Yanya'ya hareket etmişlerdir. $^{75}$

${ }^{69}$ DAB-OA, Dahiliye Nezareti Siyasi Kısım Evrakı (DH. SYS), 99/3, H. 30.09.1330 (12 Eylül 1912).

${ }^{70}$ DAB-OA, DH.SYS, 99/3, H. 30.09.1330 (12 Eylül 1912).

${ }^{71}$ DAB-OA, DH.SYS, 99/3, H. 30.09 .1330 (12 Eylül 1912).

${ }^{72}$ DAB-OA, DH.SYS, 99/3, H. 30.09.1330 (12 Eylül 1912). DAB-OA, HR.SYS, 154/2, 11 Temmuz 1912. DABOA, HR.SYS, 153/39, 16 Temmuz 1912.

${ }^{73}$ DAB-OA, HR.SYS, 153/39, 16 Temmuz 1912.

${ }^{74}$ DAB-OA, DH.SYS, 99/3, H. 30.09 .1330 (12 Eylül 1912).

${ }^{75}$ DAB-OA, HR.SYS, 153/39, 16 Temmuz 1912. 
Avlonya Kaymakam vekilinin edindiği istihbarata göre Derviş Hima ve beraberindeki firari on yedi Arnavut öğrenci, Karadağ veya Sırbistan üzerinden Arnavutluk'a geçerek İşkodra'nın kuzeyinde toplanmayı planlamaktaydılar. ${ }^{76}$ Derviş Hima tarafından silahlandırılan bu gençler, 1912 yılının Temmuz ayı ortalarında başlarında Delvine'nin Nobca köyünden bir zabitle birlikte Dıraç sahilinden Arnavutluk'a çıkmışlardır. ${ }^{77}$

Derviş Hima, beraberindeki çoğu öğrenci yaklaşık yüz kadar silahlı Arnavut'la birlikte Yanya vilayetine bağlı Ergiri sancağında dolaşmaya başlamıştır. Yakalanmaları için müfrezeler çıkarılmış ve sıkı bir takibat başlatılmıştır. ${ }^{78}$ Derviş Hima, Yanya vilayetinde aleni bir şekilde halkı ihtilale teşvik etmiştir. Öyle ki o günlerde yaşanan olayları teskin etmek için Yanya ve çevresinde çetelerin takibinin bırakılması yönünde bir karar alındığında Yanya valisi, Derviş Hima ve arkadaşlarının da bu uygulamaya dâhil olup olmadığını sormaktan kendisini alamamıştır. ${ }^{79}$

II. Meşrutiyetin ilanı öncesi Enver ve Niyazi Bey gibi “dağa çıkan” Derviş Hima, 21 Temmuz'da Sadrazamlığa getirilen Ahmet Muhtar Paşa'ya 4 A ğustos 1912'de Ergiri dağlarından bir mektup göndermiştir. "Darülfünun Arnavut Talebesi Namına Arnavut Gazetesi Müdürü Derviş Hima" şeklinde imzaladığı bu mektuba yeni kurulan hükümetin her tarafta olduğu gibi ihtilal mahfillerince de büyük bir sevinçle karşılandığını belirterek başlamıştır. Yeni hükümetin ihtilalciler ile askerler arasında dökülen kana bir nihayet vermek için aldığı tedbirlerin sevinçle karşılandığını ancak bu sevincin ölmek için dağa çıkan Arnavut gençlerini hayatlarından endişe ettikleri için değil yeni hükümetle anlaşabilecekleri düşüncesinden kaynaklandığını da ifade etmiştir. Gazi Ahmet Muhtar Paşa isminin Arnavutluk'ta saygın bir yere sahip olduğu belirtildikten sonra Yanya Valisi Mehmed Ali Bey'in kendilerine yönelik bir "tedmir ve tenkil" politikası takip ettiğinden bahsederek validen şikâyetçi olmuştur. ${ }^{80}$

İsyanlar bastırılmaya çalışılırken alınan askerî tedbirlerin faydadan çok zarar getirdiğine inanan Gazi Ahmet Muhtar Paşa, isyanın güç kullanarak değil ikna ve taleplerin kabulü yoluyla bastırılmasını istiyordu. ${ }^{81} \mathrm{Bu}$ mektup karşısında da 7 Ağustos'ta Dâhiliye Nezaretinden Derviş Hima'ya nasihatte bulunularak bu işten vazgeçmesinin sağlanmasını istemiştir. $^{82}$

Tüm bu olaylar yaşanırken İstanbul'da Arnavut gazetesi yayınlanmaya devam etmiş ve bir müddet sonra Derviş Hima İstanbul'a dönmüştür. İsyan büyük oranda bastırılmak üzereyken 8 Ekim 1912'de Karadağ'ın Osmanlı Devleti'ne savaş ilanıyla birlikte Balkan Harbi başlamıştır. Artık Rumeli coğrafyasında Osmanlı varlığı sona ermek üzeredir. Savaşın ilk günlerinde Hima, gazetesindeki yazılarında Arnavutların sadakat ve samimiyetle bağlı bulundukları Osmanlı Devletini, "hukuk-1 kavmiye ve Osmaniyelerini" muhafaza edeceklerini ifade etmiştir. ${ }^{83}$ Ancak ilerleyen günlerde savaşın seyrine bağlı olarak kaygı ve endişesi Osmanlılık ve Osmanlı ülkesinden daha ziyade Arnavutlar ve Arnavutluk'un geleceği üzerine yoğunlaşmaya başlamıştır. 25 Ekim 1912 tarihinde kaleme aldığı makalesinde gelinen son noktada ya Arnavutluk'un idam fermanın ya da bağımsızlık beratının tasdik edileceğini ifade

\footnotetext{
${ }^{76}$ DAB-OA, DH.SYS, 99/3, H. 30.09 .1330 (12 Eylül 1912).

${ }^{77}$ DAB-OA, DH.SYS, 99/3, H. 30.09 .1330 (12 Eylül 1912).

${ }^{78}$ DAB-OA, DH.SYS, 99/3, H. 30.09.1330 (12 Eylül 1912).

${ }^{79}$ DAB-OA, Babiali Evrak Odası Evrak1 (BEO), 4067/304996, H. 16.08.1330 (31 Temmuz 1912). DAB-OA, BEO, 4070/305208, H. 24.08.1330 (8 Ağustos 1912).

${ }^{80}$ DAB-OA, BEO, 4070/305208, H. 24.08.1330 (8 Ağustos 1912).

${ }^{81}$ Maden, agm., s. 177.

${ }^{82}$ DAB-OA, DH.SYS, 99/3, H. 30.09.1330 (12 Eylül 1912). DAB-OA, BEO, 4070/305208, H. 24.08 .1330 (8 Ağustos 1912).

${ }^{83}$ Derviş Hima, "Harb ve Arnavutluk", Arnavut, Nu: 73, 5 Teşrinievvel 1328 (18 Ekim 1912), s. 1.
} 
ettikten sonra Surbistan, Yunanistan ve Karadağ'ın Arnavutları ve Arnavutluk'u ortadan kaldırmak, Arnavutluk'u parçalamak istediklerini belirtmiştir. Aynı makalede tüm bu yaşananların müsebbibi olarak itham ettiğgi İttihatçıların Arnavutluk'un Osmanlı Devleti'nin Rumeli'de varlığı için ne kadar önemli olduğunu anlamadıklarını ifade etmiştir. ${ }^{84}$

Arnavutlar, 28 Kasım 1912'de İsmail Kemal önderliğinde bağımsızlıklarını ilan ederek geçici bir hükümet kurarlarken; ${ }^{85}$ aynı günlerde Derviş Hima da İstanbul'dan ayrılarak Peşte üzerinden Arnavutluk'a doğru yola çıkmıştır. ${ }^{86}$

\section{Arnavutluk’un Bağımsızlığından Sonraki Faaliyetleri ve Vefatı}

27 Şubat - 6 Mart 1912 tarihlerinde düzenlenen Trieste Kongresi’ne katılan Derviş Hima, Faik Konitza, Hile Mosi ve Fazıl Toptani ile birlikte kongrenin öne çıkan simalarından biri olmuştur. ${ }^{87} 1913$ yılındaki Londra Konferansıyla Arnavutluk'un bağımsızlığı tanınmışsa da Birinci Dünya Savaşı'nın başlamasıyla birlikte toprakları, Sırbistan, Karadağ, Yunanistan, İtalya ve Avusturya tarafından işgal edilmiştir. ${ }^{88}$

1916 yılı Mart ayının ilk günlerinde Derviş Hima, Osmanlı Devletinin Sofya Sefaretine başvurarak Avrupa'ya gitmek için Osmanlı pasaportu talebinde bulunmuştur. Ancak, Arnavutluk'ta Bulgaristan'ın menfaatlerine yönelik faaliyetlerde bulunması nedeniyle pasaport talebi olumsuz karşılanmıştır. ${ }^{89} \mathrm{Bu}$ talebinden yaklaşık bir hafta sonra Derviş Hima, Koniçalı Faik ve Hasan Basri Beyle birlikte bu kez Peş'te ortaya çıkmıştır. 17 Mart'ta Peşte Başşehbenderliğini ziyaret eden Derviş Hima, Arnavutluk'un geleceğinin manen Osmanlı Devletine iktisadî açıdan da Avusturya'ya bağlı olduğunu bundan dolayı da "Macarların muhabbetini celb etmek için" oraya gittiğini ve gerekirse burada yayın faaliyetlerinde bulunacağını ifade etmiştir. ${ }^{90}$ Bir müddet Avusturya'da kalan Derviş Hima, buradan Romanya'daki arkadaşı İbrahim Temo'ya üzerinde Enver Paşa'nın fotoğrafının bulunduğu bir kartpostal (Ek 2) göndererek Arnavutluk'a gitmeye çalıştığından bahsetmiştir. ${ }^{91}$

1917 yılının sonbaharında işgalci Avusturya kuvvetleri tarafından Tiran'da okul müfettişi olarak görevlendirilen Derviş Hima, Ahmet Zogu yönetiminde Arnavutluk'un ilk Basın Yayın Genel Müdürlüğüne getirilmiştir. 13 Nisan 1928 'de 56 yaşında Tiran'da vefat etmiştir. ${ }^{92}$

Ahmet Bedevi Kuran, gençliğinde ateşli bir ihtilalci olarak nitelendirdiği Derviş Hima’nın meşrutiyetin ilanından sonra ilk etapta Osmanlı İmparatorluğu içinde muhtar bir Arnavutluk talebinde bulunduğunu bir müddet sonra da Arnavutluk'un bağımsızlığı için çalıştığını ifade

${ }^{84}$ Derviş Hima, “Kevare-i Vatan Tehlikede!”, Arnavut, Nu: 74, 12 Teşrinievvel 1328 (25 Ekim 1912), s. 1.

855 Aralı 1912 tarihli Sabah gazetesinde Neue Freie Presse gazetesinden iktibas yapılarak verilen "Arnavutluk'ta Hükümet-i Muvakkate Teşkili” başlıklı haberde Derviş Hima'nın da adı kabine üyeleri arasında sayılmıştır. Ancak Derviş Hima söz konusu listede yer almamıştır. “Arnavutluk’ta Hükümet-i Muvakkate Teşkili”, Sabah, Nu: 8337, 25 Zilhicce 1330 (5 Aralık 1912).

${ }^{86}$ Peşte'de bulunduğu esnada Derviş Hima'nın Pester Lioyd gazetesinde bir mütalaası yayımlanmıştır. Söz konusu mütalaa Sabah gazetesinin 4 Aralık 1912 tarihli nüshasında yayımlanmıştır. "Arnavutluk Meselesi", Sabah, Nu: 8337, 24 Zilhicce 1330 (4 Aralik 1912), s. 2.

${ }^{87}$ Robert Elsie, "Congress of Trieste (1913)", Historical Dictionary of Albania, 2nd ed., The Scarecrow Press, Lanham 2010, s. 90.

${ }^{88}$ İhsan Burak Birecikli, “Arnavutluk Tahtı İçin Mücadele: Arnavutluk Prensi Kim Olacak?”, Trakya Üniversitesi Edebiyat Fakültesi Dergisi, C. 6, S. 11 (Ocak 2016), s. 127.

${ }^{89}$ DAB-OA, Hariciye Nezareti İdare (HR.ID), 68/45, 4 Mart 1916.

${ }^{90}$ DAB-OA, HR.SYS, 2072/53, 17 Mart 1916. DAB-OA, Dahiliye Nezareti Emniyet-i Umumiye Müdüriyeti Birinci Şube (DH.EUM.1.Şb), 7/13, H. 14.11.1335 (1 Eylül 1917).

${ }^{91}$ DAB-OA, DH.EUM.1.Şb, 7/13, H. 14.11 .1335 (1 Eylül 1917).

92 Robert Elsie, "Hima, Dervish Bey (1873-13.04.1928)", A Biographical Dictionary of Albanian History, I.B. Tauris, London - New York 2012, s. 203. 
eder. Ona göre Derviş Hima, "müstakil Arnavutluk’ta Kral Zogu zamanında sefalet ve istırap içinde ölmüştür." ${ }^{93}$ Avlonyalı Ekrem Bey, Derviş Hima'nın son günleri hakkında Kuran'dan daha farkı bir görüşe sahiptir. Ekrem Bey, İstanbul'da Arnavut gazetesini çıkarırken oldukça yakından tanıdığı Derviş Hima ve son günleri hakkında şu bilgileri vermiştir:

“Cenevre'de Lenin'le tanışarak onunla yakın dost oldu. Derviş Hima sosyalistti ama komünist değildi... Dış görünüşü ve tarzı, 1848 ila 1860 arasındaki ilerici fikirlerin idealist öncülerini hatırlatıyordu. Derviş Hima, Arnavutluk'taki faaliyetlerini, pek çok kişi tarafindan eleştirilmesine yol açan, zahmeti az, maaşı dolgun bir memuriyetle sonlandırdl - cumhuriyetin o zamanki başkanı Ahmet (Bey) Zogu tarafindan basin-yayın genel müdürlüğ̈̈ne getirildi."

Derviş Hima, 1926 yılında Yusuf Bey Dibra (Dashishti) tarafından Ahmet Zogu'ya karşı tertip edilen bir hareketin içerisinde yer almışsa da hareketin içinde yer alanları ihbar ederek komployu akamete uğratmıştır. ${ }^{94}$

İbrahim Temo, Ahmed Rıza'nın vefatı sonrası düzenlenen cenaze merasimine devlet erkânın ve halkın ilgisiz davranması ve yalnızca 60-70 kişinin katılması üzerine 26 Mart 1930'da "Ahmet Rıza Bey Hakkında" başlıklı bir yazı kaleme almıştır. Yazıda başka ülkelerde topluma ve vatana hizmet eden insanlara gösterilen vefaya dair örnekler vermiştir. Verdiği örneklerden biri de Derviş Hima'nın vefatı sonrası ona gösterilen vefa olmuştur. İbrahim Temo, yazısında şu ifadelere yer vermiştir: "Tiranda Derviş Hima vefat ediyor bütün şehir ahalisi, parlamento azasl, düvel-i ecnebiye mümessilleri, hatta kral bile çelenk göndererek ihtifalata iştirak ediyor." 95

\section{Eserleri:}

\section{Çare-i Necat Besa Besadadır:}

29 Ocak 1899'da kaleme alınan dört sayfalık kitapçı, "Arnavutlar! Ey vatan kardeşlerimiz! Biz kimiz biliyor musunuz?" şeklinde bir sesleniş ve soruyla başlıyor. Bu soruya cevap mahiyetinde Büyük İskender'in torunları oldukları; akıl ve zekâları, ahde vefada göstermiş oldukları sebat sayesinde birçok milletler üzerinde hâkimiyet kurdukları; İskender Bey'in çeyrek asır boyunca Osmanlı Devleti'ne karşı mücadele ettiği; Osmanlı'nın ıslah ve selameti için çalışan Köprülüler, Koçi Bey, Sinan Paşa, Tepedelenli Ali Paşa ve Sinan Paşa'nın Arnavut olduğu cevabı verilmiştir. Böylece millî kimlik inşasının en önemli unsurlarından biri olan tarih ön plana çıkarılarak millî gurur kabartılmaya çalışılmıştır.

Her ne kadar Osmanlı idarî taksimatında Arnavutluk kavramı yoksa da Arnavutların yoğun olarak yaşadıkları bölgeyi ifade etmek için dönemin resmî yazışmalarında sık sık kullanılmıştır. Kitapta, Yanya, Manastır, Kosova ve İşkodra vilayetlerinin tek bir vatan olduğu ifade edilerek Arnavutluk'un sınırları tespit edilmiş oluyordu. Yazar, Arnavutlardan milli meclisler kurmalarını ve bu meclislerden birer azanın "Plegsia" adını verdiği umumi ve millî meclise gönderilmesini istemiştir. Ayrıca eğitim, bayındırlık, ziraat, sosyal ve askeri alanlarda Arnavutların ihtiyaçları belirtilmiştir. Metin, "milletimizi, vatanımızı kurtaracak, namusumuzu muhafaza edecek ve bizi âlem-i medeniyete karşı mahcup bırakmayacak ancak son bir ahd bir ittifak-1 umumidir. Yani Besa Bes’tir. Yaşasın kavmimiz, mahvolsun düşmanlarımız." ifadeleriyle sonlandırılmıştır. ${ }^{96}$

\footnotetext{
${ }^{93}$ Kuran, Inkılap Tarihimiz ..., s. 202.

${ }^{94}$ Avlonyalı Ekrem Bey, age., dip. 14, s. 241.

95 İbrahim Temo, “Ahmet Riza Hakkında Bey Hakkında”, İçtihad, Nu: 295, 15 Nisan 1930, ss. 5370-5371.

${ }^{96}$ Derviş Hima, Çare-i Necat Besa Besadadır, 14 Kânunusani 1317 (29 Ocak 1899).
} 


\section{Uyanalım:}

22 Nisan 1899'da basılan risale, "kahr-1 hükümete ve vatandaşlarının hıyanetine uğrayan Fraşerli Abdül Bey'in ruh-i mübarekine" ifadesiyle Şemseddin Sami'nin ağabeyi Arnavut milliyetçiliğinin önemli simalarından Abdül Bey’e ithaf edilmiştir. Bir İki Söz başlığı altında kaleme alınan önsöz mahiyetindeki ilk sayfalarda 1897 Osmanl1-Yunan Harbi'nin Osmanlı zaferiyle neticelenmiş ve birçok yer zapt edilmiş olmasına rağmen buraların tekrar terk edilmesi ve Girit'in Rumlara bırakılması eleştirilmiştir. "Vatandaşlar!" şeklinde hitap edilen Arnavutlara bu kitapları neşredenlerin onların selametini, saadetini, ikbalini ve istiklalini düşünenler olduğu ifade edilmiştir. Kitapta belirgin bir şekilde Osmanlı Devleti ve Osmanlı hükümeti ifadelerinin yerine Türkiye kavramı kullanılmış olması dikkat çekmektedir. Arnavutlara millî bir bilinç kazandırmak amacıyla kaleme alınan kitapta Arnavut'un Arnavut'tan başka dostu olmayacağ 1 düşüncesi, "Arnavutluk'un selametini Arnavutlardan ziyade bir kimsenin gözeteceğine onun yolunda başkalarının ada-yı vatanla çarpışacağına kail olmak kadar hamakat olamaz" şeklinde ifade edilmiştir. 1877-1878 Osmanl1-Rus Harbi sonrası Arnavutların meskûn bulundukları Ülgün, Bar, Podgoriçe ve Narta gibi toprakların düşmanlara teslim edilmesi eleştirildikten sonra ileride meydana gelecek bir savaş veya nümayiş neticesinde Arnavutluk'un birçok yerinin düşmana bırakılabileceği değerlendirmesi yapılmıştır. Kitapta Arnavutların "besa bes" olarak nitelendirdikleri onur sözü, "ahd ve misak-1 millî" olarak tanımlanarak Arnavutluk'un selameti için "Türkiye'den" şu sekiz talepte bulunulmuştur: 1. Arnavut okullarının açılarak; Arnavutçanın yanında Türkçe öğretiminin zorunlu kılınması, 2. Arnavutluk'ta bir ihtiyar meclisi kurularak buradaki müzakerelerin Arnavutça ve Türkçe yapılması, 3. Gelirlerin Arnavutluk'ta demiryolu inşası, yolların ve köprülerin tamiri, fabrikaların kurulması, nehirlerin gemi seferlerine uygun hale getirilmesi için harcanması, 4. Yeni bir nüfus sayımı yapılarak buradan alınacak askerlerin Arnavutluk'un sınırlarında görevlendirilmesi, 5. Memurların bir komisyon tarafından yapılacak sinav neticesinde atanması, 6. Manastır, İşkodra, Yanya ve Kosova'ya bir valinin tayin edilmesi, 7. Sürgüne gönderilmiş olanların mahkeme edilerek suçluların cezalandırılması, 8. Din ve mezhep farkı gözetmeksizin kanunların adalet ve hakkaniyet çerçevesinde uygulanması. ${ }^{97}$

\section{Makber-i Ahrar:}

Derviş Hima'nın 13 Şubat 1901 tarihinde neşrettiği on sekiz sayfalık risale, II. Abdülhamid'in öldürttüğü veya ölümüne sebep olduğu iddia edilen on dokuz kişi hakkında kısa bir takım bilgileri içermektedir. Derviş Hima, II. Abdülhamid hakkında oldukça ağır ithamlara ve ifadelere yer verdiği risaleyi kaleme alış nedenini, bir katil olarak nitelendirdiği Abdülhamid'in işlediğini iddia ettiği cinayetlerin bazılarını göz önüne sererek "padişah ve halife tanınan şahs-ı melunun ne zehirli bir yllan, ne can yakıcı bir ifrit, ne sokucu bir akrep, ne yırtıcı bir kaplan olduğunu göstererek" vatan görevini yerine getirmek olarak ifade etmiştir. Daha önce yayınladığı risalelerle birlikte bu risalenin satışından elde edilecek hasılatı II. Abdülhamid'in zalim pençelerinde kurban olduklarını söylediği şehitler için Mevlut okutarak arkalarından birer Fatiha göndermek için sarf edileceğini belirtmiştir.

Risalede hakkında bilgi verilen ilk kişi, 20 Mayıs 1878'de Çırağan Baskını ile Abdülhamid'i tahttan indirerek yerine tekrar V. Murad'1 geçirmek isteyen Ali Suavi olmuştur. Baskın esnasında Ali Suavi'nin Beşiktaş Karakol Kumandanı Hasan Çavuş tarafından öldürülmesiyle Sultan Hamid'in "şehit-i akdesin kanını bu suretle" içtiği ifade edilmiştir.

Risalede hakkında en fazla bilgi verilen kişi, Midhat Paşa olmuştur. Midhat Paşa'nın Kanun-i Esasi'nin ilanındaki rolü ve Abdülaziz'in şüpheli ölümü üzerine kurulan Yııldız

${ }^{97}$ Derviş Hima, Uyanalım, 10 Nisan 1899. 
Mahkemesindeki yargılama neticesinde idam cezasına çarptırılması ve bu cezanın sürgüne çevrilmesi üzerinde durulduktan sonra Taif’teki ölümü ve sonrasında yaşanan olaylar hakkında ilgi çekici bilgiler verilmiştir. Derviş Hima'ya göre Midhat Paşa'nın çarptırıldı̆̆ı idam cezasının sürgüne çevrilmesi, Abdülhamid'in hafiyeleri, casusları, saray hademeleri vasıtasıyla kahvehanelerde, evlerde ve camilerde ne kadar yüksek bir merhamete sahip olduğu yönünde kamuoyuna propaganda yapmaktan başka bir amaç taşımıyordu. Derviş Hima'nın ileri sürdüğü iddialardan en dikkat çekicisi, Midhat Paşa'nın Taif'te Abdülhamid vasıtasıyla boğdurularak öldürülmesi ve cenaze defnedilmiş olmasına rağmen, Abdülhamid'in isteği üzerine cenazenin çıkarılarak başının gövdesinden ayrılıp İstanbul'a gönderilmesidir. Derviş Hima konuyla ilgili olarak özetle şunları ifade etmiştir:

“Öldüğünden emin olmak için Midhat Paşa'nın başını görmek istedi. Cenaze gömülmüştü. Tekrar çıkardılar. Hayvanlara bile icra edilmeyen hakaretlerle baltalarla başını boynundan ayırdılar. Bir sandiğa yerleştirdiler. Sandı̆̆ın üzerine 'Halife ve Padişaha Hediye' diye yazdılar. Melunlar Allah'tan korkmadılar ve düşünmediler ki ilahi adalet hiçbir zulmeti gizli bırakmaz. Sandık bendegân ile beraber Süveyş Kanalından geçerken gümrükçüler açıp içindekini görmek istediler. Bendegân-ı Halife ısrar ettiler. Zât-ı şahaneye olan hediye gümrükte açllmaz dediler. İstanbul'a telgraf çektiler. Sultan Hamid çıldırmaya başladl. Ingiltere Kraliçesi müteveffa Victoria'ya telgraf çekilerek zatına ait olan hediyelerin Süveyş'ten muayenesiz geçmesini rica etti. Kraliçe verdiği cevapta diyordu ki mümkünsüzdür. Ben imzaladı̆̆ım bir kanunu çiğneyemem. Nizamı ayaklar altına aldı̆̆ım dakikada saltanatım mahvolmuş demektir. Memurlarn vazifelerini icrada tam bir hürriyete sahip olduklarını arz ile arzunuzu yerine getiremediğim için müteessifim. Bu cevap katilin cümle-i acibesine dokundu. Sultan haktan korkmayarak icra ettiği bir cinayetin halk arasinda şüyu bulmasindan imparatorlar, krallar, kraliçeler, şehzadeler arasında bed nam olacağından asla çekinmedi. Sandık açıldı. Dehşetli cinayet meydana çıktt. Haber kraliçeye kadar ulaştı. Globe, Daily Mail, Standart, Times gibi gazetelerde çıkan haber ve makaleler ile cinayet tüm dünyaya duyuruldu."

Risalede ayrıca Mahmud Celaledin Paşa, Şeyhülislam Hayrullah Efendi, Namık Kemal Bey, Ali Şefkati Bey, Süleyman Paşa, Selanikli Doktor Ahmed Bahtiyar Efendi, Kabasakallı Halid Efendi, Beykozlu Ali Zühdü Bey, Şakir Paşa, Sâib Paşa, Şeyh Hamdi, Doktor Vamık Bey, Zeki Meğamiz, Mehmed Efendi Ali Kanunî, Hoca Mehmed Rüşdü Efendi gibi isimler hakkında da çeşitli bilgiler verilmiştir. ${ }^{98}$

Derviş Hima'nın Roma'da neşrettiği risaleden Osmanlı postanelerine ulaşmasıyla haberdar olan hükümet ve Yıldız, hızlı bir şekilde risalenin ülkeye sokulmasını ve dağıtılmasını yasaklamıştır ${ }^{99}$.

\section{Cinâyât-ı Seniyyeden Bir Levha:}

Derviş Hima'nın 3 Mart 1901'de Roma'da neşrettiği risalelerden biridir. Önsöz mahiyetinde kaleme alınan "Saray Halkına" başlığı altında kitabın yazılma gerekçesi hakkında bilgiler verilmiştir. II. Abdülhamid'in yanında yer alan saray ve devlet erkânına hitap edilerek küçük bir iftira, ehemmiyetsiz bir ihmal ve küçük bir hareketleri neticesinde "zalim" olarak nitelendirilen Abdülhamid'in gazabına uğrayabilecekleri ifade edilmiştir. "Ey cah-1 dünya ile gözleri görmeyen ikbalperestler!” şeklinde hitap edilen saray çevresine ileride bir gün Abdülhamid'in yerine Sultan Reşad'ın geçmesiyle birlikte işledikleri cinayetlerden; aldıkları

\footnotetext{
${ }^{98}$ Derviş Hima, Makber-i Ahrar, 13 Şubat 1901, s. 4-7.

${ }^{99}$ DAB-OA, DH.MKT, 2457/81, H. 14.11.1318 (5 Mart 1901).
} 
rüşvetlerle devlet hazinesini zarara uğratmaktan; vatan topraklarını tahrip etmek ve satmaktan sorumlu tutulacakları belirtilerek kaleme alınan bu eserin onlara bir ibret olması temenni edilmiştir.

Kitabın devamında ise L'Observateur gazetesinde Abdülhamid ve saraya ait bazı sırların yayımlanmasının yarattı̆̆ı huzursuzluk ve buna bağlı olarak Münir Bey ve Hidayet Beyin oyunları neticesinde Mabeyn kâtiplerinden Küçük Kadri Bey'in iftiralar ve ithamlar neticesinde nasıl öldürüldüğ̈̈ anlatılmıştır. Risalenin sonunda Abdülahmid'e ağır hakaretler içeren iki şiire yer verilmiştir. ${ }^{100}$

\section{Sadr-ı Esbak Merhum Rifat Paşa'nın Mahdumu Cavid Bey Merhumun Sebeb-i Mevti Olan İkinci Layiha:}

Derviş Hima'nın “Cavid Bey Merhumun Türkçe Fransızca Birinci Layihası” başlığıyla daha önce yayınladığı dizinin ikinci kitabı olarak da nitelendirilebilecek bu çalışma, Cavid Bey tarafından Abdülhamid'e sunulan layihayı içermektedir. 1903 yılında Cenevre'de yayınlanan bu risale, Derviş Hima'nın "Bir İki Söz” başlığıyla kaleme aldığı bir önsözle başlamaktadır. Önsöze kitapta da yer alan Cavid Bey’in bir resmini Roma'ya doğru yaptığı bir tren yolculuğu esnasında tanıştığı Belçikalı bir tüccar vasıtasıyla temin ettiğini teferruatlı bir şekilde anlatarak başlar. Devamında ise hem Sultan Abdülhamid'e hem de dönemin Roma Sefiri Reşid Beye yönelik galiz hakaretler ve ithamlar yöneltilmiştir. Önsözden hemen sonra "Layiha Sureti" başlığı altında Cavid Bey'in Arnavutluk-Makedonya hakkında kaleme alarak Abdülhamid'e sunduğu rapora yer verilmiştir. Kitabın sonunda kısa bir değerlendirme yapan Derviş Hima, eğer söz konusu layiha dikkate alınarak tavsiye dilen çözüm yolları hayata geçirilmiş olsaydı; o gün için Rumeli'de ve Arnavutluk'ta yaşanan gaileler yaşanmayacağı, Arnavutluk'ta boş yere insanların kanının akmayacağı kanaatindedir. Ona göre Abdülhamid, layiha vasıtasıyla hakikatleri dile getiren Cavid Beyi öldürtmüştür. ${ }^{101}$ Ağır hakaret ve iddiaların yer aldığı bu risaleden Ağustos ayında haberdar olan Osmanlı hükümeti, vilayetlerden ve ilgi nazırlıklardan bu "hezeyannamenin" ülkeye girmesine ve dağıtılmasına "zinhar meydan verilmemesini" eğer ülkeye gelen varsa onların hemen toplattırılarak imha edilmesini istemiştir. ${ }^{102}$

\section{Devr-i Hürriyette Zindandan Bir Sada}

Derviş Hima, Meşrutiyetin ilanından kısa bir müddet sonra otonomi talebi yönündeki söylem ve eylemlerinden dolayı bir müddet İşkodra hapishanesinde tutuklu kalmıştır. ${ }^{103} \mathrm{Bu}$ dönemde kaleme aldığı, on beş sayfalık risale, 1908 yılında Selanik'te basılmıştır. Risalenin sonunda Arnavut gençlerine hitap ederek onlardan Arnavutça okuyup yazmaya önem vermelerini istemiştir. Bu isteğini şu ifadelerle dile getirmiştir: "Kadmos'un getirdiği güzel ve tarihî hurufatla okuyalım. Ben başka bir şey bilmem. Okuyalım. İstediğimiz Arnavutça serbest yazıp okumaktı. Siyaseti, politika işlerini büyük diplomatlara bırakalım. Biz Arnavutça

\footnotetext{
100 Derviş Hima, Cinâyât-ı Seniyyeden Bir Levha, Roma 3 Mart 1901. Söz konusu risale yazışmalarda kısaca "Cinayet" adıyla geçmektedir. DAB-OA, Yıldız Mütenevvî Maruzat Evrakı (Y.MTV), 213/178, H. 26.12.1318 (16 Nisan 1901).

${ }^{101}$ Derviş Hima, Sadr-ı Esbak Merhum Rifat Paşa’nın Mahdumu Cavid Bey Merhumun Sebeb-i Mevti Olan Íkinci Layiha, Cenevre 20 Temmuz 1903. Bu dönemde Halil Rifat Paşa'nın diğer oğlu Ahmed Bey de Cenevre'ye kaçmıştır. Burada bir yandan ticaretle meşgul olurken bir yandan da buraya kaçmıs firarilerle sürekli temas halinde olmuştur. En fazla görüştüğü isimlerden biri de Derviş Hima'dır. Paris Sefiri Münir Bey, Yıldıza göndermiş olduğu bir yazıda kim olduğunu bilmediğimiz Halil isminde biri ile Derviş Hima'nın dalkavukluk ederek Ahmed Beyin parasını yediklerini ve ona akıl hocalığı yapmakta olduklarını belirtmiştir. Aziz Esenbel, "Sadrazam Halil Rıfat Paşanın Oğlu Ahmed Beyin Avrupaya Firarı", Tarih Dünyası, C. 2, S. 18, ss. 782-784.

${ }^{102}$ DAB-OA, DH.MKT. 757/2, H. 02.06.1321 (26 Ağustos 1903).

${ }^{103}$ Peter Bartl, Milli Bağımsızlık Hareketleri Esnasında Arnavutluk Müslümanları (1878-1912), Çev.: Ali Taner, Bedir Yayınevi, İstanbul, 1998, s. 240.
} 
okuyalım. Bu nur-i maariften parlak istikballer doğacak. Uhuvvet, ittihat yol alacak, ada ve husema hissinden, kibrinden kahr ve kemnam olacak. Olsun!.. Arnavutçaya düşman olanlar bila istisna kahrolsun! Evet, bizi sevmeyen düşmanlar kahrolsun!"104

\section{Musavver Arnavut:}

Arnavut gazetesinin tatil edildiği 7 Ekim - 13 Aralık 1910 tarihleri arasında Derviş Hima, İstanbul'da bulunan Arnavut ileri gelenlerini gazetenin idarehanesinde bir araya getirerek "Arnavut Heyet-i Edebiyyesi" adında ilmî bir cemiyet kurmuştur. Kurulan cemiyetin programında amaçları ifade edilirken Arnavutların diğer "akvam-1 Osmaniyenin" sahip olduğu medenî ve edebî seviyeye ulaşmasını sağlamak için gerekli olan edebî, iktisadî ve sosyal alanlarda çalışma yapmak olduğu belirtilmiştir. Arnavut millî edebiyatının gelişmesi için edebî ve ilmî eserlerin üretilmesini teşvik etmek amaciyla her sene sonunda heyet tarafindan beğenilen bir çalışmanın bastırılacağı ve yazarına da bir ödül verileceği belirtilmiştir. Bununla birlikte heyetin amaçları arasında bir kütüphane oluşturmak da vard $1^{105}$.

Arnavut Heyet-i Edebiyesi'nin neşrettiği ilk kitap olan Musavver Arnavut, farklı içeriklere sahip olmak üzere Türkçe ve Arnavutça yayınlanmıştır. Kitabın Türkçe kısmında Abidin Paşa, Recep Paşa, Hoca Tahsin, Vasa Paşa gibi Arnavut asıllı isimlerin biyografilerine yer verildiği gibi Avlonyalı Süreyya Efendi'nin kaleme aldığı "Tarih-i Osmani'de Arnavutluk", Derviş Hima'nın kaleme aldığı "Arnavutluk Vekayi-i Ahiresi”, "Luma Vekayiinin Esbab-1 Zuhuru", "İhtilal” gibi makalelere yer verilmiştir. Kitap, birkaç makale dışında, genel olarak Derviş Hima tarafından kaleme alınmıştır. ${ }^{106}$

\section{Diğer Eserleri}

Derviş Hima'nın bu kitaplarının yanı sıra, Ümid-i İkaz, Çare-i Necat, Sultan Hamid ve Şeyh Hamdi'nin Defa-i Şehadeti, Efendi ve Bende: Sultan ile Onu Haraca Kesen Bükreş Sefili Rezili Şantaj Kazım'dan Bahis'tir, Müslüman Arnavutlara Beyanname-i Şer'i gibi eserleri de vardır. Yurtdışında yayımlanan tüm bu risalelerin yayınlanmalarından kısa bir müddet sonra alınan kararlarla ülkeye sokulması yasaklanmıştır. ${ }^{107}$ Ülkeye girişi yasaklanan bu risaleler, Avusturya postanesi aracılığıyla Osmanlı ülkesine sokuluyor ve gizli bir şekilde dağıtılıyordu. Kitapların yurda girişi ve dağıtımına karşı hükümetin alabildiği tedbir, ilgili kurumlara gerekli tedbir alınması yönünde emirler vermekten öteye geçememiştir ${ }^{108}$.

Derviş Hima, Abdullah Cevdet'in "Yaşamak Korkusu" isimli makalesini İbrahim Temo'nun önsözü ve kendisinin kaleme aldığı "Şehid-i Zişan Doktor İshak Sükûtî" başlıklı bir giriş yazısıyla "Arnavut kütüphanesinin birinci risalesi olmak üzere" 1910 yılının Nisan ayının ilk günlerinde basarak otuz para karşı1lığında satışa sunmuştur ${ }^{109}$. Abdullah Cevdet’in İbrahim Temo'ya onun da Derviş Hima'ya ulaştırması neticesinde 23 sayfalık bir risaleye dönüşen bu makalenin satışından elde edilen gelir, 9 Şubat 1902 'de San Remo'da vefat ederek orada

\footnotetext{
${ }^{104}$ Derviş Hima, Devr-i Hürriyette Zindandan Bir Sada, Asır Matbaası, Selanik 1908, s. 15.

${ }^{105}$ Derviş Hima, Musavver Arnavut, Matbaa-i Şems, İstanbul 1327 (1910), s. 110-111.

${ }^{106}$ Derviş Hima, Musavver..., s. 5-109.

${ }^{107}$ DAB-OA, Yıldız Mütenevvî Maruzat Evrakı (Y.MTV), 164/206, H. 11.03.1315 (10 Ağustos 1897). DAB-OA, DH.MKT. 795/43, H. 28.08.1321 (19 Kasim 1903). DAB-OA, DH:MKT, 2354/155, 05.02.1318 (4 Haziran 1900).

${ }^{108}$ DAB-OA, Y.MTV, 213/178 H. 26.12.1318 (16 Nisan 1901). DAB-OA, DH.MKT, 2457/81, H. 14.11 .1318 (5 Mart 1901).

109 "Yaşamak Korkusu”, Arnavut, Nu: 15, 9 Nisan 1326 (22 Nisan 1910) s. 6.
} 
defnedilen İshak Sükûtî'nin mezarının 1909'da İstanbul'da Sultan Mahmud Türbesine taşınması sonrası inşa edilen mezarı için açılan yardım sandığına bağışlanacaktı ${ }^{110}$.

\section{Sonuc}

Hem Jön Türk hareketinin hem de Arnavut milliyetçiliğinin önemli isimleri arasında yer alan Derviş Hima, dönemin şartlarına bağlı olarak bir yandan Arnavutlar arasında millî bir kimliğin gelişimi için mücadele ederken bir yandan da Osmanlılık kimliğini ön plana çıkararak Osmanlı unsurlarının birlik ve beraberliğinin sağlanması düşüncesini savunmuştur. Bir taraftan Arnavut milliyetçiliği ve Arnavutlara özerklik verilmesi talebinde bulunurken bir taraftan da Osmanlı Devletinin bekasını savunması bir çelişki olarak görülebilir. Ancak o dönemde farklı etnik kökene mensup birçok Osmanlı aydını aynı düşünceyle hareket etmiştir. II. Meşrutiyetin ilanı öncesi İttihat ve Terakki ile oldukça yakın ilişki içerisinde olduğunu gördügümüz Derviş Hima, meşrutiyet sonrası bunu devam ettirememiştir. Özellikle özerklik yönündeki söylem ve eylemleri bunda etkili olmuştur.

Öğrenciliği döneminde II. Abdülhamid'e karşı gelişen muhalif hareket içerisinde yer alan Derviş Hima, eğitimini bırakarak İstanbul'dan ayrılmış; bir müddet Arnavutluk coğrafyasında siyasî bir takım faaliyetlerde bulunduktan sonra, dönemin birçok muhalifinin yaptığ 1 gibi o da, yurt dışına çıkmıştır. Yurt dışına çıkışından sonra Romanya, İtalya, İsviçre ve Paris gibi ülkelerde bulunan Derviş Hima, siyasi faaliyetlerinin yanı sıra yoğun bir şekilde yayıncılık faaliyetlerinde bulunmuştur. Çıkarmış olduğu Arnavutluk ve Arnavut gazeteleri ile kitapçıklarda dil, tarih ve kültür konuları üzerinde durarak Arnavut millî kimliğinin inşası sürecinde önemli bir rol üstlenmiştir. II. Meşrutiyet öncesi kaleme aldığı risalelerin en dikkat çekici ortak özelliği, II. Abdülhamid'e karşı yürütülen amansız muhalefet ve ona yöneltilen galiz hakaretlerdir.

II. Meşrutiyetin ilanından sonra İstanbul'da çıkardığı Arnavut gazetesinde üzerinde en fazla yoğunlaştığ konu, Arnavutçanın yaygınlaştırılması olmuştur. Bu çerçevede çıkardığı gazetenin bir bölümünü Arnavutça yayınlamıştır. Bu dönemde arka arkaya Arnavut dili ve Arnavutların eğitimiyle ilgili olarak gerçekleştirilen kongrelere katılarak yadsınamaz katkılarda bulunmuştur. Belirgin bir şekilde İttihat Terakki yönetimiyle karşı karşıya gelmeye başlayan Derviş Hima, özerklik yönündeki talepleri ve bu yönde Arnavut kamuoyu nezdinde yürüttügü propaganda faaliyetleri nedeniyle meşrutiyetin ilanından hemen sonra hapis hyatmıştır.

Arnavutluk'un bağımsızlığı sürecinde aktif rol alan Derviş Hima, 1912 yılında Kuzey Arnavutluk'ta başlayan isyanın Arnavutluk'un geneline yayılmasında oldukça etkili olmuştur. Balkan Savaşının yarattığı ortamdan istifade eden Arnavutların bağımsızlıklarını ilan etmelerinden sonra aktif olarak politikanın içerisinde yer almaya devam etmiştir. Ancak I. Dünya Savaşı ile Arnavutluk topraklarının işgal edilmesi ve sonrasında yaşanan olaylar, Arnavutları birçok sıkıntıyla karşı karşıya getirmiştir. Bu dönemde Derviş Hima'nın da içerisinde bulunduğu birçok Arnavut siyasetçi, Arnavutluk’un varlığının Osmanlı Devleti’nin

\footnotetext{
${ }^{110}$ Abdullah Cevdet, "Yaşamak Korkusu" başlığıyla yazdığı makaleyi "Bu makalenin bahası bir liradır ve bu lira birader-i şehidimiz İshak Sükûtî’nin mezarı için iane sandığına aittir.” şeklindeki bir pusulayla İbrahim Temo'ya göndermiştir. İbrahim Temo, makaleyi bastırmak üzere o günkü dergilerden birine giderken yolda Derviş Hima ile karşılaşır. Makaleyi okuyan Hima, Temo’ya hemen bir lira verdiği gibi makaleyi risale şeklinde basip elde edilen gelirin mezar inşası masraflarına kullanılmasını teklif eder. Abdullah Cevdet, Osmanlı ülkesinde "memuriyetperestlik" olarak tercüme ettiği Fransızca fonctionnarisme (officialdom, functionalism) kavramı üzerinden herkesin memur olmak istemesini eleştirdiği bu makalesinde "teşebbüs-i şahsi" yani girişimciliği teşvik eder. Doktor Abdullah Cevdet, Yaşamak Korkusu, Naşiri: Arnavut Gazetesi Müdürü Derviş Hima, Matbaa-i Cihan, Dersaadet 1326.
} 
manevi desteğine bağlı olduğunu ifade ederek destek arayışına girmişlerse de kendi başının derdine düşen Osmanlı Devleti'nin elinden bir şey gelmemiştir.

\section{KAYNAKÇA}

Arşiv Belgeleri

\section{Devlet Arşivleri Başkanlığı - Osmanlı Arşivi (DAB-OA)}

Babıali Evrak Odası Evrakı (BEO)

4067/304996, H. 16.08.1330 (31 Temmuz 1912).

4070/305208, H. 24.08.1330 (8 Ağustos 1912).

Dahiliye Nezareti Emniyet-i Umumiye Müdüriyeti Birinci Şube (DH.EUM.1.Şb)

7/13, H. 14.11.1335 (1 Eylül 1917).

Dahiliye Nezareti Emniyet-i Umumiye Tahrirat Kalemi Evrakı (DH.EUM.THR)

38/64, H. 19.06.1328 (28 Haziran 1910).

93/64, H. 16.12.1327 (29 Aralık 1909).

Dahiliye Nezareti Mektubi Kalemi (DH.MKT)

795/43, H. 28.08.1321 (19 Kasım 1903).

757/2, H. 02.06.1321 (26 Ağustos 1903).

2240/37, Hicrî (H.) 21.04.1317 (29 Ağustos 1899).

2457/81, H. 14.11.1318 (5 Mart 1901).

2844/58, H. 26.05.1327 (15 Haziran 1909).

Dâhiliye Nezareti Muhaberat-ı Umumiye İdaresi Evrakı (DH.MUI)

80/30, H. 25.06.1328 (4 Temmuz 1910).

97/21, H. 27.07.1328 (14 Ağustos 1909).

Dâhiliye Nezareti Siyasi Kısım Evrakı (DH.SYS)

57/4, H. 08.10.1328 (13 Ekim 1910).

99/3, H. 30.09.1330 (12 Eylül 1912).

Hariciye Nezareti Idare (HR.ID)

68/45, 4 Mart 1916.

Hariciye Nezareti Siyasî (HR.SYS)

117/55, 6 Haziran 1902.

129/24, 13 Ekim 1899.

129/25, 28 Ekim 1899.

130/28, 25 Haziran 1903.

153/39, 16 Temmuz 1912. 
154/2, 11 Temmuz 1912.

155/22, 24 Haziran 1903.

155/47, 11 Kasim 1908.

1764/7, 13 Eylül 1903.

1809/47, 7 Mart 1901.

2072/53, 17 Mart 1916.

Sadâret Mektubî Kalemi Mühimme Kalemi Belgeleri (A.MKT.MHM)

730/10, H. 10.01.1321 (8 Nisan 1903).

Yıldız Mütenevvî Maruzat Evrakı (Y.MTV)

164/206, H. 11.03.1315 (10 Ağustos 1897).

213/178, H. 26.12.1318 (16 Nisan 1901).

Yıldız Perakende Evrakı Elçilik, Şehbenderlik ve Ateşemiliterlik Maruzâtı (Y.PRK.EŞA) 39/64, 04.11.1319 (12 Şubat 1902).

40/43, H. 26.02.1320 (4 Haziran 1902).

Yıldız Sadâret Hususî Maruzât Evrakı (Y.A.HUS)

400/104, H. 09.06.1317 (15 Ekim 1899).

429/116, H. 27.02.1320 (5 Haziran 1902).

450/136, H. 29.03.1321 (25 Haziran 1903).

450/141, H. 30.03.1321 (26 Haziran 1903).

\section{Kitap ve Makaleler}

“Arnavut Hurufatı”, Arnavut, Nu: 2, 7 Kânunusani 1325 (20 Ocak 1910), s. 1.

“Arnavut Hurufu Meselesinde Gizli Noktalar", Arnavut, Nu: 7, 11 Şubat 1325 (24 Şubat 1910), s. 1.

“Arnavut Hurufu, Hükümet Bitaraf Kalıyor”, Arnavut, Nu: 5, 28 Kânunusani 1325 (10 Şubat 1910), s. 1.

“Arnavut Kongresi”, Yeni Tasvir-i Efkâr, Nu: 104, 12 Eylül 1909, s. 6 (2. Sütun).

“Arnavut Lisanı Hakkında”, Arnavut, Nu: 1, 31 Kânunuevvel 1325 (31 Ocak 1910), s. 2.

“Arnavut'un İfadesi”, Arnavut, Nu: 40, 30 Teşrinisani 1326 (13 Aralık 1910), s. 1.

“Arnavut'un Muhterem Karileri”, Arnavut, Nu: 18, 6 Mayıs 1326 (19 Mayıs 1910), s. 2.

“Arnavutça Harfler Meselesi”, Arnavut, Nu: 4, 21 Kânunusani 1325 (3 Şubat 1910), s. 1.

“Arnavutluk Ahvâli", Arnavut, Nu: 16, 15 Nisan 1326 (28 Nisan 1910), s. 1-2.

“Arnavutluk Meselesi”, Sabah, Nu: 8337, 24 Zilhicce 1330 (4 Aralık 1912), s. 2.

“Arnavutluk’ta Hükümet-i Muvakkate Teşkili”, Sabah, Nu: 8337, 25 Zilhicce 1330 (5 Aralık 1912). 
“Derviş Hima ve Tasvir-i Efkâr”, Arnavut, Nu: 15, 9 Nisan 1326 (22 Nisan 1909), s. 1-2.

“Ípek Mebusu Bedri Beyin Nutku Münasebetiyle -Hurufat Meselesi- ”, Arnavut, Nu: 13, 1 Nisan 1326 (14 Nisan 1910), s. 1-2.

“Lisan”, Arnavut, Nu: 44, 25 Kânunuevvel 1326 (7 Ocak 1911), s. 1.

“Meclis-i Vükelanın Nazargahına”, Arnavut, Nu: 20, 22 Mayıs 1326 (4 Haziran 1910), s. 1.

"Yaşamak Korkusu", Arnavut, Nu: 15, 9 Nisan 1326 (22 Nisan 1910) s. 6.

AKŞì, Sina, Jön Türkler ve İttihat ve Terakki, İmge Yay., 6. Baskı, İstanbul 2011.

Arnavut, Nu: 1, 31 Kânunuevvel 1325 (13 Ocak 1910), s. 1.

Avlonyalı Ekrem Bey, Osmanlı Arnavutluk'undan Anılar (1885-1912), çev. Atilla Dirim, İletişim Yay., İstanbul 2006.

AYDIN, Mithat, "Bükreş’te Komitacılık Faaliyetleri (1860-1916)", Çağdaş Türkiye Tarihi Araşstırmaları Dergisi, C. 15, S. 30 (2015/Bahar), ss. 5-52.

BARTL, Peter, Milli Bağımsızlık Hareketleri Esnasında Arnavutluk Müslümanları (18781912), Çev.: Ali Taner, Bedir Yayınevi, İstanbul, 1998.

BİRECİKLİ, İhsan Burak, "Arnavutluk Tahtı İçin Mücadele: Arnavutluk Prensi Kim Olacak?", Trakya Üniversitesi Edebiyat Fakültesi Dergisi, C. 6, S. 11 (Ocak 2016), ss. 123-146.

BLUMI, İsa, Publishers, Hitmen, Diplomats, and Dreamers: Switzerland's OttomanAlbanian Diaspora, 1899-1920, Schweizerische Zeitschrift für Geschichte = Revue suisse d'histoire = Rivista storica svizzera, Volume 52 (2002), ss. 309-320.

CLAYER, Nathalie, Arnavut Milliyetçiliğinin Kökenleri Avrupa'da Çoğunluğu Müslüman Bir Ulusun Doğuşu, çev. Ali Berktay, 1. Baskı, Bilgi Üniversitesi Yay., İstanbul Haziran 2013.

ÇELİK, Bilgin, İttihatçılar ve Arnavutlar, Büke Kitaplığı, İstanbul Ağustos 2004.

Derviş Hima, "Harb ve Arnavutluk", Arnavut, Nu: 73, 5 Teşrinievvel 1328 (18 Ekim 1912), s. 1.

Derviş Hima, “Kevare-i Vatan Tehlikede!”, Arnavut, Nu: 74, 12 Teşrinievvel 1328 (25 Ekim 1912), s. 1.

Derviş Hima, "Vatandaşlara İfademiz", Arnavut, Nu: 1, 31 Kânunuevvel 1325 (13 Ocak 1910), s. 1.

Derviş Hima, Cinâyât-ı Seniyyeden Bir Levha, Roma 3 Mart 1901.

Derviş Hima, Çare-i Necat Besa Besadadır, 14 Kânunusani 1317 (29 Ocak 1899).

Derviş Hima, Devr-i Hürriyette Zindandan Bir Sada, Asır Matbaası Selanik 1908.

Derviş Hima, Makber-i Ahrar, 13 Şubat 1901.

Derviş Hima, Musavver Arnavut, Matbaa-i Şems, İstanbul 1327 (1910).

Derviş Hima, Sadr-ı Esbak Merhum Rifat Paşa'nın Mahdumu Cavid Bey Merhumun Sebeb-i Mevti Olan İkinci Layiha, Cenevre 20 Temmuz 1903. 
Derviş Hima, Uyanalım, 10 Nisan 1899.

Doktor Abdullah Cevdet, Yaşamak Korkusu, Naşiri: Arnavut Gazetesi Müdürü Derviş Hima, Matbaa-i Cihan, Dersaadet 1326.

ELSIE, Robert, "Congress of Trieste (1913)", Historical Dictionary of Albania, 2nd ed., The Scarecrow Press, Lanham 2010, s. 90.

ELSIE, Robert, "Hima, Dervish Bey (1873-13 April 1928)", Historical Dictionary of Albania, 2nd ed., The Scarecrow Press, Lanham 2010, ss. 191-192.

ELSIE, Robert, "Hima, Dervish Bey (1873-13.04.1928)", A Biographical Dictionary of Albanian History, I.B. Tauris, London - New York 2012, s. 202-203.

ESENBEL, Aziz, "Sadrazam Halil Rıfat Paşanın Oğlu Ahmed Beyin Avrupaya Firarı", Tarih Dünyası, C. 2, S. 18, ss. 782-784.

GAWRYCH, George, The Crescent and the Eagle: Ottoman Rule, Islam and the Albanians, 1874-1913, I.B. Tauris, New York 2006.

GJEVORI, Sokol, "Educational and Cultural Traditions in Elbasan During the Nineteenth Century - 1912”, European Scientific Journal, Vol. 10, March 2011, s. 136-144.

HANIOĞLU, M. Şükrü, “Jön Türkler”, Türkiye Diyanet Vakfi İslam Ansiklopedisi, C. 23, İstanbul 2001, ss. 584-587.

HANIOĞLU, M. Şükrü, Bir Siyasal Örgüt Olarak Osmanlı İttihad ve Terakki Cemiyeti ve Jön Türklük (1889-1902), İletişim Yay, İstanbul 1985.

HANIOĞLU, M. Şükrü, The Young Turks in Opposition, Oxford University Press, Oxford-New York 1995.

ILIKAN, Faruk, “Debre Kongresi”, Simurg, Y11: 1, S. 1, Ekim 199, ss. 200-249.

İbrahim Temo, “Ahmet Rıza Hakkında Bey Hakkında", İçtihat, No: 295, 15 Nisan 1930, ss. 5370-5371.

İbrahim Temo, İttihad ve Terakki Cemiyetinin Teşekkülü ve Hidemat-1 Vataniye ve İnkılâb-1 Milliye Dair Hatıratım, Biz İttihatçılar, Yay. Haz. Nurer Uğurlu, Örgün Yay., İstanbul Haziran 2009.

KALESHI, Hasan, "Hima, Dervish", Biographisches Lexikon zur Geschichte Südosteuropas. Bd. 2. Hgg. Mathias Bernath, Felix von Schroeder, München 1976, ss. 161-164.

KANLIDERE, Ahmet, “İttihat ve Terakki'nin Gölgede Kalmış Simalarından Doktor İshak Sükûtî (1868-1902)", Tarihçiliğe Adanmış Bir Ömür Prof. Dr. Nejat Göyünç'e Armağan, Ed. Hasan Bahar vd., Selçuk Üniversitesi Yay., Eylül 2013 İstanbul, ss. 205-216.

KARAKOÇ, Ercan, YAVAŞ, Mesut, "İkinci Meşrutiyet Döneminde Arnavutların Eğitim Çalışmalarında Önemli Bir Aşama: Elbasan Maarif Kongresi”, Belleten, C. LXXXII, S. 249 (A ğustos 2018), ss. 675-697.

KURAN, Ahmet Bedevî, Inkılap Tarihimiz ve Jön Türkler, Kaynak Yayınları, 2. Baskı, İstanbul Nisan 2000.

KURAN, Ahmet Bedevi, Osmanlı Impatorluğunda Inkılâp Hareketleri ve Millî Mücadele, Türkiye İş Bankası, Kültür Yay., İstanbul 2012. 
KÜLÇE, Süleyman, Osmanlı Tarihinde Arnavutluk, Yeni Asır Matbaas1/Ticaret Basımevi, İzmir 1944.

MADEN, Fahri, “Arnavutluk'un Bağımsızlık Süreci (1877-1913)”, TiKKA Avrasya Etüdleri, S. 38 (2011/1), ss. 155-196.

MARDİN, Şerif, Jön Türklerin Siyasî Fikirleri 1895-1908, İletişim Yayınları, 18. Bask1, İstanbul 2012.

OLGUN, Said, "Contributions Albanian Diaspora in Romania to the Development of Albanian Nationalism in the Last quarter of Nineteenth Century", Glimpses of Balkan Cultural History, Ed. Abidin Temizer, Gece Kitaplığı, Ankara 2017, ss. $27-42$.

OLGUN, Said, Arnavut Milliyetçiliğinin Gelişsiminde Mektepler, Gece Kitaplığı, Ankara 2016.

ÖZBOZDAĞLI, Özer, "Selanik, Manastır ve Kosova Vilayetlerinde 1912 Meclis-i Mebusan Seçimleri”, Gaziosmanpaşa Üniversitesi Sosyal Bilimler Araştırmaları Dergisi, C. 11, S. 2 (Kış 2016), ss. 283-315.

ÖZGEN, Yunus; BALCI, Mustafa, "II. Meşrutiyete Giden Yolda İbrahim Temo - Derviş Hima Mektuplaşması", Türk Yurdu, Y11: 97, S. 251 (Temmuz 2008), ss. 115-117.

Rıza Nur, "San Remo'da İshak Sükûtî”, Şehbâl, Nu: 15, 1 Teşrinisani 1325 (14 Kasım 1909), ss. 290-292.

SKENDI, Stavro, The Albanian National Awakening 1878-1912, Princeton University Press, New Jersey 1967.

SÖNMEZ, Banu İşlet, II. Meşrutiyette Arnavut Muhalefeti, 1. Bask1, Yap1 Kredi Yay., İstanbul, Nisan 2007.

ZEYREK, Suat, “II. Meşrutiyet'te Demokratik Muhalefetin Sonu: Arnavut İsyanları Ve Sonuçları", Erciyes Üniversitesi Sosyal Bilimler Enstitüsü Dergisi, C. 1. S. 33 (2012/1), ss. 299-336. 


\section{Ekler}

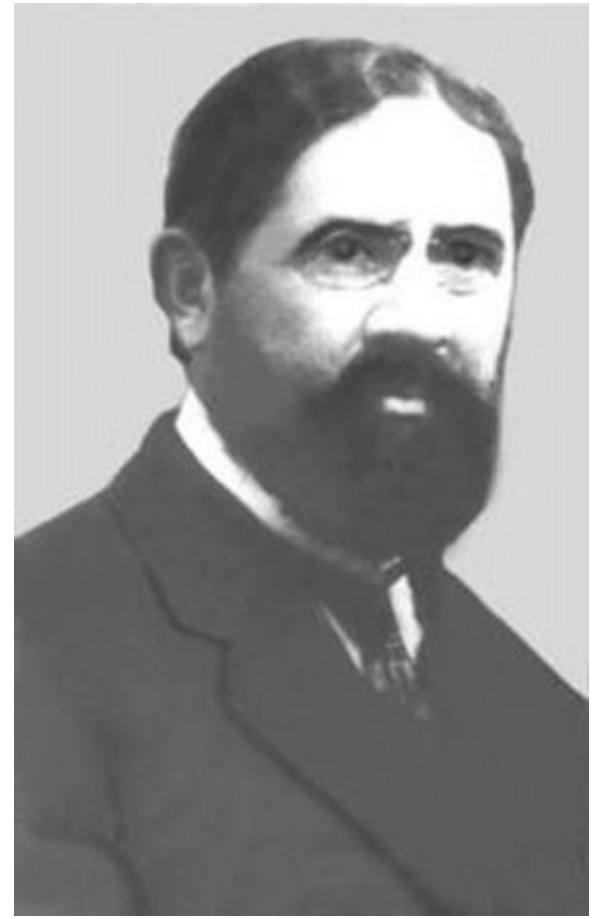

Ek 1: Derviș Hima (1872-1928)
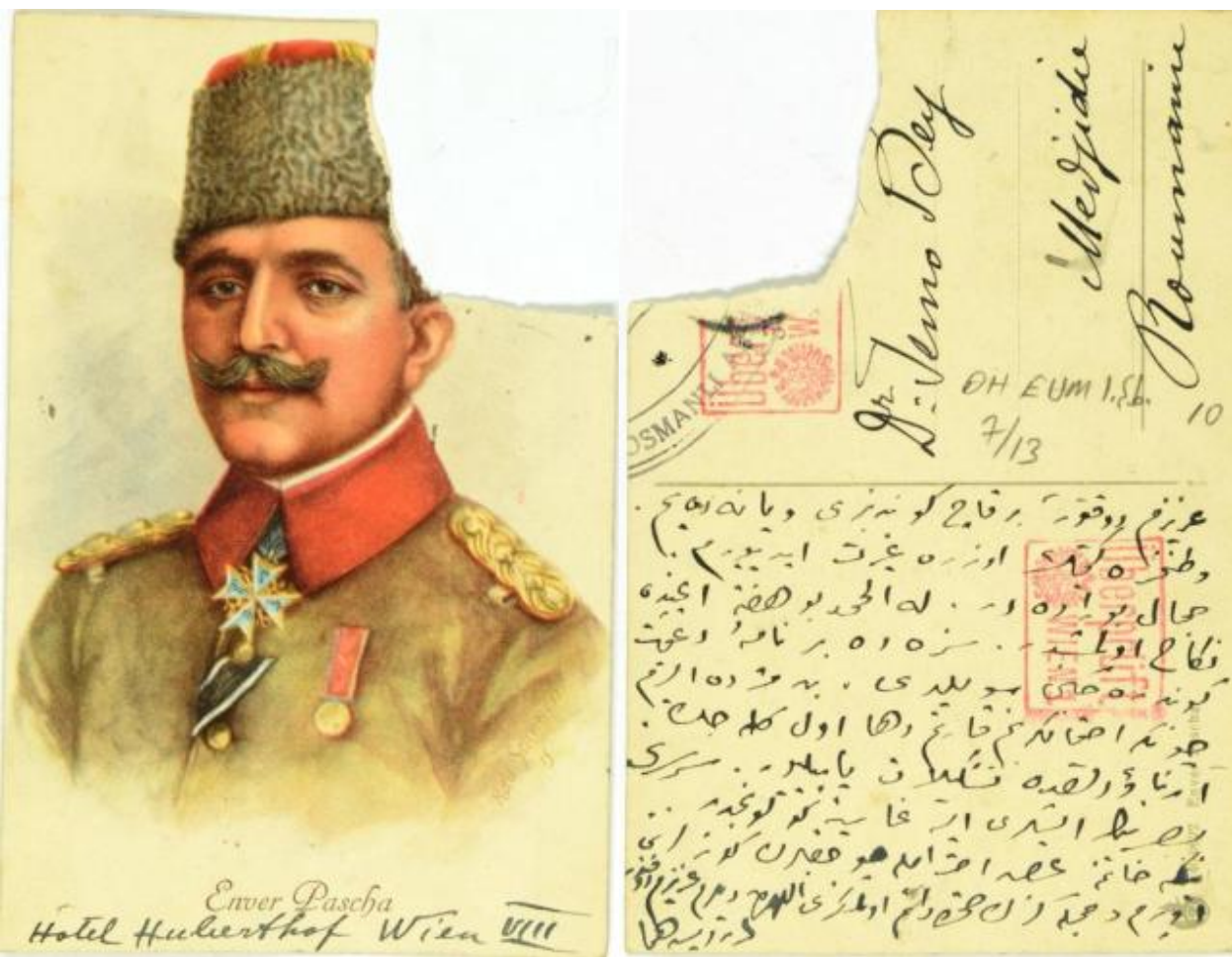

Volume 10

Issue 10

December 2018

Ek 2: Derviş Hima'nın 1917'de İbrahim Temo'ya Gönderdiği Kartpostal. DAB-OA, DH.EUM.1.Şb, 7/13, H. 14.11.1335 (1 Eylül 1917). 